Research paper

\title{
Desing and synthesis of potent anti-Trypanosoma cruzi agents new thiazoles derivatives which induce apoptotic parasite death
}

\author{
Elany Barbosa da Silva ${ }^{\mathrm{a}, \mathrm{b}}$, Dayane Albuquerque Oliveira e Silva ${ }^{\mathrm{a}}$, \\ Arsênio Rodrigues Oliveira a, Carlos Henrique da Silva Mendes a , \\ Thiago André Ramos dos Santos ${ }^{c}$, Aline Caroline da Silva ${ }^{c}$, \\ Maria Carolina Acioly de Castro ${ }^{\mathrm{c}, \mathrm{d}}$, Rafaela Salgado Ferreira ${ }^{\mathrm{b}}$, \\ Diogo Rodrigo Magalhães Moreira e, Marcos Veríssimo de Oliveira Cardoso f, \\ Carlos Alberto de Simone ${ }^{g}$, Valéria Rêgo Alves Pereira ${ }^{c}$, Ana Cristina Lima Leite ${ }^{a}{ }^{*}$ \\ a Departamento de Ciências Farmacêuticas, Centro de Ciências da Saúde, Universidade Federal de Pernambuco, 50740-520, Recife, PE, Brazil \\ b Departamento de Bioquímica e Imunologia, Universidade Federal de Minas Gerais, 31270-901, Belo Horizonte, MG, Brazil

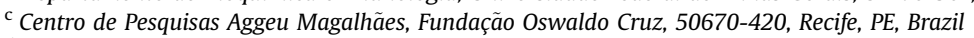 \\ d Laboratório de Parasitologia, Centro Acadêmico de Vitória, Universidade Federal de Pernambuco, 55608-680, Vitória de Santo Antão, PE, Brazil \\ e Centro de Pesquisas Gonçalo Moniz, Fundação Oswaldo Cruz, 40296-750, Salvador, BA, Brazil \\ ${ }^{\mathrm{f}}$ Colegiado de Nutrição, Campus Petrolina, Universidade de Pernambuco, 56328-903, Petrolina, PE, Brazil \\ ${ }^{\mathrm{g}}$ Departamento de Física e Informática, Instituto de Física, Universidade de São Paulo, CEP 13560-970, São Carlos, SP, Brazil
}

\section{A R T I C L E I N F O}

\section{Article history:}

Received 18 October 2016

Received in revised form

9 February 2017

Accepted 10 February 2017

Available online 16 February 2017

\section{Keywords:}

Chagas disease

Trypanosoma cruzi

Nonclassical bioisosterism

Thiazoles

Pyridine derivatives

Apoptosis

\begin{abstract}
A B S T R A C $T$
Chagas disease, caused by the kinetoplastid protozoan parasite Trypanosoma cruzi, remains a relevant cause of illness and premature death and it is estimated that 6 million to 7 million people are infected worldwide. Although chemotherapy options are limited presenting serious problems, such as low efficacy and high toxicity. T. cruzi is susceptible to thiazoles, making this class of compounds appealing for drug development. Previously, thiazoles resulted in an increase in anti-T. cruzi activity in comparison to thiosemicarbazones. Here, we report the structural planning, synthesis and anti-T. cruzi evaluation of new thiazoles derivatives (3a-m and $\mathbf{4 a - m}$ ), designed from molecular hybridization associated with nonclassical bioisosterism. By varying substituents attached to the phenyl and thiazole rings, substituents were observed to retain, enhance or greatly increase their anti-T. cruzi activity, in comparison to the corresponding thiosemicarbazones. In most cases, electron-withdrawing substituents, such as bromine, 3,4-dichloro and nitro groups, greatly increased antiparasitic activity. Specifically, new thiazoles were identified that inhibit the epimastigote proliferation and were toxic for trypomastigotes without affecting macrophages viability. These compounds were also evaluated against cruzain. However, inhibition of this enzyme was not observed, suggesting that the compounds work through another mechanism. In addition, examination of $T$. cruzi cell death showed that these molecules induce apoptosis. In conclusion, except for compounds $\mathbf{3 h}$ and $\mathbf{3 k}$, all thiazoles derivatives evaluated exhibited higher cytotoxic activity against the trypomastigote forms than the reference medicament benznidazole, without affecting macrophages viability. Compounds $\mathbf{4 d}$ and $\mathbf{4 k}$ were highlights, CC50 = 1.2 e $1.6 \mu \mathrm{M}$, respectively. Mechanistically, these compounds do not inhibit the cruzain, but induce $T$. cruzi cell death by an apoptotic process, being considered a good starting point for the development of new anti-Chagas drug candidates.
\end{abstract}

(c) 2017 Elsevier Masson SAS. All rights reserved.

\footnotetext{
* Corresponding author.

E-mail address: acllb2003@yahoo.com.br (A.C.L. Leite).
}

\section{Introduction}

Chagas disease, caused by the kinetoplastid protozoan parasite Trypanosoma cruzi (T. cruzi), remains a relevant cause of illness and premature death with 6 million to 7 million people estimated to be 
infected worldwide, mainly in Latin America. Thereby it is considered the most important parasitic disease in the Western Hemisphere $[1,2]$. Chemotherapy options are limited, with only two trypanocidal drugs available: nifurtimox ( $\mathrm{Nfx}$ ) and benznidazole (Bdz). Moreover, these drugs present serious problems, such as low efficacy and high toxicity. Only benznidazole is in common use, due to the risk of serious central nervous system and peripheral neurotoxicity with nifurtimox [3]. On the other hand, benznidazole is effective against the circulating form of the parasite (trypomastigotes) in the acute phase of the disease, but its efficacy during the chronic stage is debatable [4]. This situation has spurred the search for more effective and better tolerated therapeutics [5-7].

Several molecular targets for designing new drugs have been investigated, among which cruzain, the major cysteine protease expressed in all the life cycle stages of the parasite. This enzyme plays an important role in differentiation, cell invasion, intracellular multiplication, and immune evasion [8,9]. Furthermore, studies have demonstrated that cysteine proteinase inhibitors have trypanocidal activity with negligible mammalian toxicity $[10,11]$.

Heterocyclic thiazole derivatives are considered a privileged structure in Medicinal Chemistry, considering their potential interaction with different biological targets and anti-parasitic activity demonstrated both by in vitro [12-14] and in vivo studies [15-17]. In the same away, pyridine derivatives have been shown to be potent agents anti-T. cruzi $[18,19]$ and able to inhibit cruzain catalytic activity [20]. In our continuing effort to develop potent trypanocidal compounds our research group has exploited thiosemicarbazones and their heterocyclic bioisosters, 2-imino-1,3thiazoles and 2-iminothiazolidin-4-ones. Thereby we identified new compounds with potent activity against cruzain and T. cruzi $[7,10,21,22]$. In addition, based on molecular hybridization of the pyridine group $\mathbf{A}$ with the heterocyclic ring thiazole $\mathbf{B}$ drawn from the non-classical cyclic bioisosterism of thiosemicarbazone (Scheme 1) we obtained non-toxic and potent inhibitors of T. cruzi and cruzain [20].

In light of these findings, we turned our attention towards the structural optimization and further identification new anti-T. cruzi 2-(pyridin-2-yl)thiazoles. Structural modifications were performed by insertion of substituents on the $\mathrm{N} 3$ position of the thiazole ring due to previous results showing derivatives with phenyl or methyl groups in N3 as potent trypanocidal agents [15,17,23]. Here, we prepared twenty four new thiazoles. In this synthetic design a range of substituents were considered for the phenyl ring attached to the thiazole moiety to examine their role to the antiparasitic activity and rationally the observed trends in terms of electronic and steric contributions.

Evaluation of the anti-T. cruzi activity for compounds (3a-m, 4am), which possess different substituents in phenyl ring in the scaffold shown in Scheme 2, allowed to establish structure-activity relationships (SAR) regarding the trypomastigote form. Besides, it was possible the identification of new compounds equally or more potent than benznidazole.

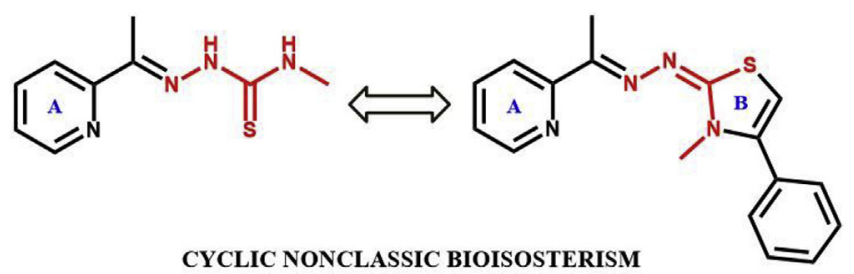

Scheme 1. Design of the 2-(pyridin-2-yl)-1,3-thiazoles derivatives through strategy of cyclic non-classic biososterism.

\section{Results and discussion}

\subsection{Synthesis}

The synthetic procedures employed in 2-(pyridin-2-yl)-1,3thiazoles (3a-m, 4a-m) preparation is shown in Scheme 2. First, 2-acetyl-2-pyridine $(\mathbf{1})$ reacted with thiosemicarbazides (methyl and phenyl-thiosemicarbazide) via Schiff base condensations in acidic conditions at room temperature. After $2 \mathrm{~h}$ of reaction, thiosemicarbazones (2a-b) compounds were obtained with higher yields than $80 \%$. Compounds (2a-b) were then reacted with halosubstituted acetophenones via Hantsch cyclization in an ultrasound bath using propanol as a solvent and short times, similar to a protocol previously described [20]. After 1 h, 2-(pyridin-2-yl)-1,3thiazoles (3a-m, 4a-m) precipitated in the reaction mixture and were collected by simple filtration. Some thiazoles were obtained pure and those with impurities (3d, 3e, 3f, 3g, 3h, 3i, 3j, 31, 4b, 4e, $\mathbf{4 h}, \mathbf{4 i}, \mathbf{4 l}$ and $\mathbf{4 m}$ ) were recrystallized with overall yields ranging from 30 to $100 \%$ while $\mathbf{3 k}$ was purified for column chromatography with $50 \%$ yield.

The purified 2-(pyridin-2-yl)-1,3-thiazoles were characterized by usual spectroscopy. As exemplified with the ${ }^{1} \mathrm{H}$ NMR analysis of 4-(4-fluorophenyl)-3-methyl-2-(1-(pyridin-2-yl)ethylidene)hydrazono)-2,3-dihydrothiazole (3e), the singlet peak at $\delta 2.42$ corresponds to the methyl group in the imine carbon and a second singlet peak at $\delta 3.35$ to the methyl group in the thiazole ring. The aromatic protons occurred as doublets, triplets or multiplet. For the pyridyl ring, peaks were observed at $\delta 7.58,7.80,8.09$ and 8.56 . For the aromatic ring coupled to the thiazole ring, multiplet peak were found at $\delta 7.33$. For the thiazole ring, a singlet at $\delta 6.46$ was observed. The ${ }^{13} \mathrm{C}$ NMR spectrum of $3 \mathbf{e}$ indicates disappearance of the ${ }^{13} \mathrm{C}=\mathrm{S}$ resonance from the parent thiosemicarbazone while a new ${ }^{13} \mathrm{C}-\mathrm{H}$ resonance appeared at $100 \mathrm{ppm}$, confirming cyclization. Quaternary carbon peaks were confirmed by DEPT experiments to appear at $\delta 126,139,148,155,156,161$ and 169. Peaks of the pyridine aromatic carbons were found at $\delta 119,123,136,148$ and 155. Resonances from the phenyl ring coupled to the thiazole ring were observed at $\delta 115.68,115.89,126,131.07,131.16$ and 161. A combination of ${ }^{1} \mathrm{H}$ and ${ }^{13} \mathrm{C}$ NMR, DEPT, IR and HRMS confirmed the purity and identity of all the compounds. Crystallization was achieved only for compound 2a (Fig. 1).

The ${ }^{1} \mathrm{H}$ NMR spectra of $\mathbf{4 b}$ and $\mathbf{4 d}$ compounds showed that they are composed by diastereomers. For this series, it was not possible to obtain crystals able to make crystallographic assays. Based on previous crystallized analoguess by our group, we suggest that the major isomer formed present the $E-Z$ configuration (Supplementary Material). Indeed, hydrazine double-bond C2 $=\mathrm{N} 2$ is commonly assigned as $E$ configuration $[20,34,35]$. Concerning the exocyclic double-bond $\mathrm{N} 3=\mathrm{C} 3$, we suggest that the predominant configuration is in Z-configuration [20,23,24]. Besides, a representative ${ }^{1} \mathrm{H}$ NMR spectrum of compound $\mathbf{4 b}$ is presented as Supplementary Material.

\subsection{Pharmacological evaluation}

After structural characterization of 2-(pyridin-2-yl)-1,3thiazoles (3a-m and $\mathbf{4 a - m}$ ), the antiparasitic and host cell cytotoxicity was determined. First, compounds were evaluated concerning their ability to inhibit the epimastigote proliferation of T. cruzi Dm28 strain, as well as their toxicity against Y strain trypomastigotes. Results were respectively expressed in terms of $\mathrm{IC}_{50}$ and $\mathrm{CC}_{50}$ values. Following this, cytotoxicity was determined in J774A.1 macrophages and results were expressed as the highest non-cytotoxic concentration (HNC) and given in $\mu \mathrm{M}$. Benznidazole $(\mathrm{Bdz})$ was used as a reference antiparasitic drug and exhibited $\mathrm{CC}_{50}$ 
<smiles>[R]NC(=S)NN</smiles><smiles>[R]NC(=S)N/N=C(\C)c1ccccn1</smiles><smiles>[114CH3]</smiles>

\begin{tabular}{|c|c|c|c|c|c|c|c|}
\hline Comp & $\mathbf{R}^{1}$ & $R^{2}$ & $\mathbf{R}^{3}$ & Comp. & $\mathbf{R}^{1}$ & $\mathbf{R}^{2}$ & $\mathbf{R}^{3}$ \\
\hline $3 a$ & : & $\mathrm{Ph}$ & $\mathrm{H}$ & $4 a$ & : & $\mathrm{Ph}$ & $\mathrm{H}$ \\
\hline $3 b$ & : & $\mathrm{Ph}$ & $\mathrm{Me}$ & 4b & : & $\mathrm{Ph}$ & $\mathrm{Me}$ \\
\hline $3 c$ & : & 4-Ph-Ph & $\mathrm{H}$ & $4 c$ & : & 4-Ph-Ph & $\mathrm{H}$ \\
\hline $3 d$ & $:$ & 4-MeO-Ph & $\mathrm{H}$ & $4 d$ & : & 4-MeO-Ph & $\mathrm{H}$ \\
\hline $3 e$ & : & $4-F-P h$ & $\mathrm{H}$ & $4 e$ & : & 4-F-Ph & $\mathrm{H}$ \\
\hline $3 f$ & : & $4-\mathrm{Cl}-\mathrm{Ph}$ & $\mathrm{H}$ & $4 f$ & : & 4-Cl-Ph & $\mathrm{H}$ \\
\hline $3 g$ & : Me & $4-\mathrm{Br}-\mathrm{Ph}$ & $\mathrm{H}$ & $4 g$ & : $\mathrm{Ph}$ & $4-\mathrm{Br}-\mathrm{Ph}$ & $\mathrm{H}$ \\
\hline $3 h$ & : & $4-\mathrm{NO}_{2}-\mathrm{Ph}$ & $\mathrm{H}$ & $4 h$ & : & $4-\mathrm{NO}_{2}-\mathrm{Ph}$ & $\mathrm{H}$ \\
\hline $3 \mathbf{i}$ & $:$ & $3-\mathrm{NO}_{2}-\mathrm{Ph}$ & $\mathrm{H}$ & $4 i$ & : & $3-\mathrm{NO}_{2}-\mathrm{Ph}$ & $\mathrm{H}$ \\
\hline $3 \mathbf{j}$ & : & 3,4-diCl-Ph & $\mathrm{H}$ & $4 j$ & : & $3,4-d i \mathrm{Cl}-\mathrm{Ph}$ & $\mathrm{H}$ \\
\hline $3 k$ & : & 2,4-diCl-Ph & $\mathrm{H}$ & $4 k$ & : & 2,4-diCl-Ph & $\mathrm{H}$ \\
\hline 31 & : & $4-\mathrm{Br}-\mathrm{Ph}$ & Me & 41 & : & 4-Br-Ph & $\mathrm{Me}$ \\
\hline $3 m$ & : & 2-Naph & $\mathrm{H}$ & $4 m$ & & 2-Naph & \\
\hline
\end{tabular}<smiles>[R3]c1s/c(=N\N=C(/C)c2ccccn2)n([R7])c1[R]</smiles>

Scheme 2. Synthetic procedures for thiosemicarbazones (2a-b) and 2-(pyridin-2-yl)-1,3-thiazoles (3a-m; $\mathbf{4 a - m}$ ). Reagents and conditions: (a) 4-methyl-3-thiosemicarbazide or 4phenyl-3-thiosemicarbazide, ethanol, acetic acid (5 drops), rt, 120 min; (b) halo-substituted acetophenones, 2-propanol, ultrasound irradiation, r. t., 60 min; $\mathrm{R}^{3}=\mathrm{H}$ for all compounds, except to (3b), (31), (4b) and (4l) where $R_{3}=$ Me.

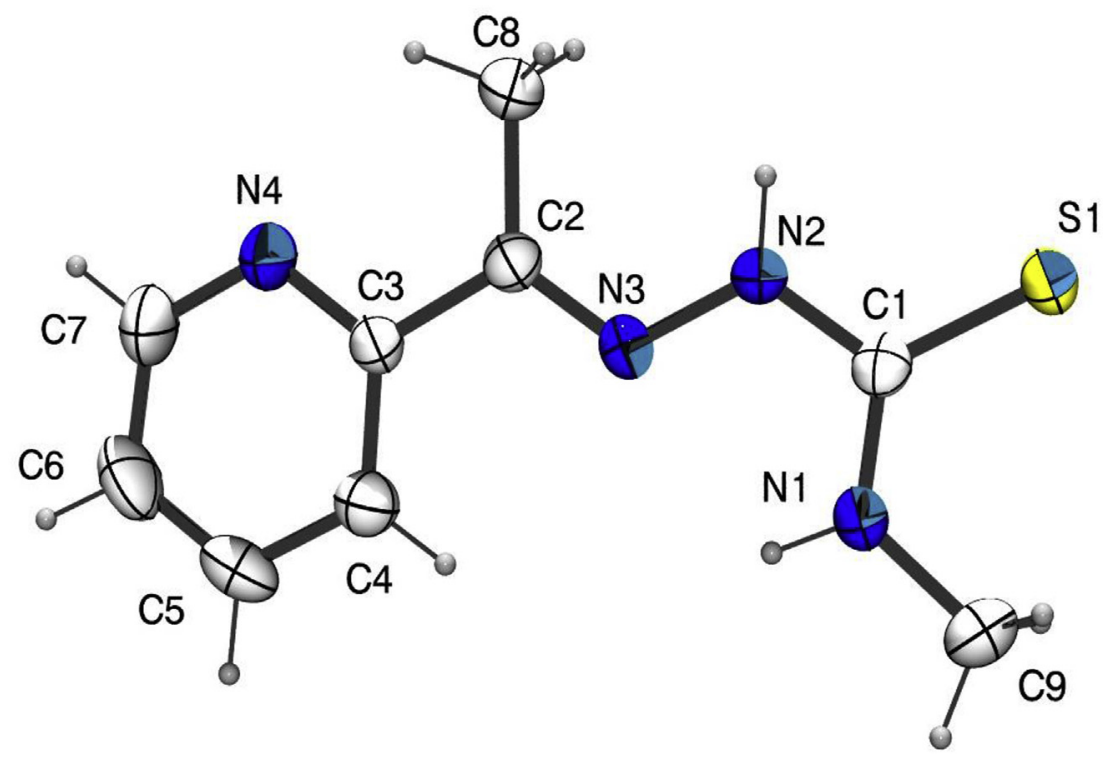

Fig. 1. ORTEP-3 projection of compound (2a) showing atom-numbering and displacement ellipsoids at the $50 \%$ probability level.

value of $6.2 \mu \mathrm{M}$ against trypomastigotes. Compounds which exhibited lower $\mathrm{CC}_{50}$ than $\mathrm{Bdz}$ in this assay were considered active anti-T. cruzi agents [25].

Table 1 shows results of anti-T. cruzi activity of the compounds 3a-m. Almost all of the thirteen compounds tested presented trypanocidal properties higher than Bdz, with the exception of compounds $\mathbf{2 a}$ (intermediary thiosemicarbazone), $\mathbf{3 h}$ and $\mathbf{3 k}$. In the $\mathbf{3 a -}$ $\mathbf{m}$ series, we highlight compounds $\mathbf{3 g}$, $\mathbf{3}$ j and $\mathbf{3 i}$, which present $\mathrm{CC}_{50}$ values of $2.2,2.3$ and $2.4 \mu \mathrm{M}$ respectively, against trypomastigotes. Based on these results the effect of the substitutions on the phenyl attached to the thiazole ring was analyzed. Concerning the activity against trypomastigotes, nonsubstituted thiazole (3a) was slightly more active $\left(\mathrm{CC}_{50}=4.0 \mu \mathrm{M}\right)$ than $\mathrm{Bdz}\left(\mathrm{CC}_{50}=6.2 \mu \mathrm{M}\right)$. We evaluated the trypanocidal activity of thiazoles containing halogen atoms attached to para-position of the phenyl ring. This peculiar substitution produced active compounds, since substituents 4bromophenyl (3g), 4-chlorophenyl (3f) and 4-fluorophenyl (3e) presented $\mathrm{CC}_{50}$ values of $2.2,4.5$ and $5.6 \mu \mathrm{M}$, respectively. Regarding the thiazoles containing two chlorines attached to the phenyl ring, a divergence in their trypanocidal capabilities was 
Table 1

Anti-T. cruzi activities of 2-(pyridin-2-yl)-1,3-thiazoles 3a-m.

\begin{tabular}{|c|c|c|c|c|c|c|}
\hline \multirow[t]{2}{*}{ Compd. } & \multirow[t]{2}{*}{$\mathrm{R}^{2}$} & \multirow[t]{2}{*}{$\mathrm{R}^{3}$} & \multicolumn{2}{|l|}{ T. cruzi } & \multirow[t]{2}{*}{ Cytotoxicity $\mathrm{HNC}[\mu \mathrm{M}]^{\mathrm{C}}$} & \multirow[t]{2}{*}{$\mathrm{SI}^{\mathrm{d}}$} \\
\hline & & & Trypomastigotes $\mathrm{CC}_{50}[\mu \mathrm{M}]^{\mathrm{a}}$ & Epimastigotes $\mathrm{CC}_{50}[\mu \mathrm{M}]^{\mathrm{b}}$ & & \\
\hline & & & & & & \\
\hline $2 a$ & - & - & 8.8 & ND & 22 & 2.5 \\
\hline $3 a$ & $\mathrm{Ph}$ & $\mathrm{H}$ & 4 & 56 & 4 & 1 \\
\hline 3b & $\mathrm{Ph}$ & $\mathrm{Me}$ & 2.7 & 6.2 & 97 & 36 \\
\hline $3 c$ & 4-PhPh & $\mathrm{H}$ & 2.2 & 66.6 & 6 & 3 \\
\hline 3d & 4-OMePh & $\mathrm{H}$ & 4.6 & 4.5 & 20 & 4 \\
\hline $3 e$ & 4-FPh & $\mathrm{H}$ & 5.6 & 8.5 & 12 & 2 \\
\hline $3 f$ & 4-ClPh & $\mathrm{H}$ & 4.5 & ND & 20 & 4 \\
\hline $3 g$ & 4-BrPh & $\mathrm{H}$ & 2.2 & 3.2 & 33 & 15 \\
\hline $3 h$ & $4-\mathrm{NO}_{2} \mathrm{Ph}$ & $\mathrm{H}$ & 7.0 & 13.7 & 36 & 5 \\
\hline $3 \mathbf{i}$ & $3-\mathrm{NO}_{2} \mathrm{Ph}$ & $\mathrm{H}$ & 2.4 & 7.8 & 82 & 34 \\
\hline $3 \mathbf{j}$ & 3,4-diClPh & $\mathrm{H}$ & 2.3 & 6.9 & 11 & 5 \\
\hline $3 k$ & 2,4-diClPh & $\mathrm{H}$ & 13.0 & 31.6 & 14 & 1 \\
\hline 31 & 4-BrPh & $\mathrm{Me}$ & 3.4 & 2.9 & 68 & 20 \\
\hline $3 m$ & 2-Naph & $\mathrm{H}$ & 3.0 & 8.2 & 30 & 10 \\
\hline Bdz & - & - & 6.2 & 48.8 & 44.7 & 7.2 \\
\hline
\end{tabular}

HNC $=$ highest non-cytotoxic concentration.

$\mathrm{Bdz}=$ benznidazole.

$\mathrm{ND}=$ not determined.

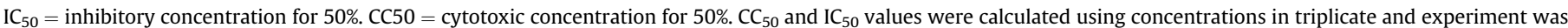
repeated, only values with a standard deviation $<10 \%$ mean were considered.

a Determined $24 \mathrm{~h}$ after incubation with compounds, using Y strain trypomastigotes.

b Determined 5 days after incubation with compounds, using Dm28c epimastigotes.

c Cell viability of J774A.1 macrophages determined $24 \mathrm{~h}$ after treatment.

d Selectivity index (SI) is the ratio of macrophages viability (HNC) to the $\mathrm{IC}_{50}$ on trypomastigotes.

observed, with 3,4-dichlorophenyl derivative (3j) being three times more active than the $\mathrm{Bdz}\left(\mathrm{CC}_{50}=2.3 \mu \mathrm{M}\right)$ while 2,4-dichlorophenyl derivative (3k) was less active with an $\mathrm{CC}_{50}$ value of $13 \mu \mathrm{M}$. Likewise, the 4-nitrophenyl derivative (3h) showed similar activity than $\mathrm{Bdz}\left(\mathrm{CC}_{50}=7.0 \mu \mathrm{M}\right)$, while the 3-nitrophenyl derivative (3i) was also three times more active than $\mathrm{Bdz}\left(\mathrm{CC}_{50}=2.4 \mu \mathrm{M}\right)$, suggesting that substitutions at the meta position of the aromatic ring were beneficial for the trypanocidal activity. In addition, compounds containing electron-donor substituents attached to the phenyl ring were also investigated. The 4-biphenylyl (3c) and 2naphthalene $(\mathbf{3 m})$ derivatives were more active than $\mathrm{Bdz}$ showing $\mathrm{CC}_{50}$ values of 2.2 and $3.0 \mu \mathrm{M}$, respectively. On the other hand, the 4-methoxyphenyl derivative (3d) was also active with a $\mathrm{CC}_{50}$ value of $4.6 \mu \mathrm{M}$ as well the nonsubstituted derivative (3a) with $\mathrm{CC}_{50}$ value of $4.0 \mu \mathrm{M}$. Another estimated effect was the insertion of methyl group attached to $\mathrm{C} 4$ of thiazole. This change resulted in minor changes of trypanocidal activity its addition leads to slightly decreased potency for the 4-bromophenyl derivative (compare $\mathbf{3 g}$, $\mathrm{CC}_{50}=2.2 \mu \mathrm{M}$ and $31, \mathrm{CC}_{50}=3.4 \mu \mathrm{M}$ ) but slightly higher potency if we consider the nonsubstituted derivative $\left(\mathbf{3 a}, \mathrm{CC}_{50}=4.0 \mu \mathrm{M}\right.$ vs $\mathbf{3 b}$, $\left.\mathrm{CC}_{50}=2.7 \mu \mathrm{M}\right)$.

Having ascertained the antiparasitic activity for trypomastigotes, we analyzed the antiproliferative activity against epimastigotes. Excluding (3c), all compounds were more active than benznidazole and able to inhibit epimastigote proliferation. The compounds (3g) and $(\mathbf{3} \mathbf{j})$, the more active against trypomastigote forms, were 15 and 7 times more potent than Bdz, respectively, to inhibit epimastigote proliferation. Regarding cytotoxicity in macrophages, some of the thiazoles exhibited low cytotoxicity. For instance, compounds (3a), (3b), (3g), (3i) and (31) present $\mathrm{CC}_{50} \leq 4.0 \mu \mathrm{M}$ against trypomastigotes, while they were non-toxic for macrophages at concentrations up to $30 \mu \mathrm{M}$. We determined the selectivity index $\left(\mathrm{CC}_{50}\right.$ macrophages $/ \mathrm{CC}_{50}$ trypomastigotes) for compounds (3b), (3g), (3i) and (31) to be 36, 15, 34 and 20, respectively.

We also assayed the inhibitory activity for thiazoles (3a-m) against the enzyme cruzain, based on kinetic assays in which the fluorescence generated by the cleavage of substrate Z-FR-AMC is monitored [14]. Compounds were screened at $50 \mu \mathrm{M}$ and the maximum perceptual of inhibition observed was 70 and $73 \%$ for compounds (3a) and (3b), respectively (data not shown). Based on these results, cruzain inhibition does not seem the mechanism of action of the trypanocidal compounds.

Next, we evaluated the anti-T. cruzi activity for compounds $\mathbf{4 a -}$ m. In this series, all compounds presented trypanocidal properties superior to Bdz, except compounds $\mathbf{4 a}$ and $\mathbf{4 m}$ that showed similar activity (Table 2). Compounds $\mathbf{4 d}$ and $\mathbf{4 k}$ were the most active within this series, being $4-5$ fold more potent than $\mathrm{Bdz}$ against trypomastigotes $\left(\mathrm{CC}_{50}=1.2\right.$ and $\left.1.6 \mu \mathrm{M}\right)$. Concerning the activity against trypomastigotes, the nonsubstituted thiazole (4a) showed activity similar than $\mathrm{Bdz}\left(\mathrm{CC}_{50}\right.$ value of $\left.6.3 \mu \mathrm{M}\right)$. We also analyzed the effect of the substitutions on the phenyl ring attached to the thiazole in this series. As observed for the series 3a-m, halogens attached to 4-position of the phenyl ring produced potent compounds, since substituents 4-bromophenyl (4g), 4-chlorophenyl (4f) and 4-fluorophenyl (4e) presented $\mathrm{CC}_{50}$ values of 1.8, 2.0 and $3.9 \mu \mathrm{M}$, respectively. The di-substitutions with chlorine atoms provided further promising compounds with $\mathrm{CC}_{50}$ values of 1.6 and $1.9 \mu \mathrm{M}$ for 2,4-dichlorophenyl derivative (4k) and 3,4-dichlorophenyl derivative $(\mathbf{4 j})$, respectively. These results corroborate with the literature data that suggest that halogen atoms cause conformational changes, which allow favorable interactions between bulky groups and the target site. Typically the strength of the interaction decreases with the size of the atomic radius, according to the following order $\mathrm{I}>\mathrm{Br}>\mathrm{Cl}[7,10,26]$ similar to that was observed for the two series here described. 
Table 2

Anti-T. cruzi activities of 2-(pyridin-2-yl)-1,3-thiazoles 4a-m.

\begin{tabular}{|c|c|c|c|c|c|c|}
\hline \multirow[t]{2}{*}{ Compd. } & \multirow[t]{2}{*}{$\mathrm{R}^{2}$} & \multirow[t]{2}{*}{$\mathrm{R}^{3}$} & \multicolumn{2}{|l|}{ T. cruzi } & \multirow[t]{2}{*}{ Cytotoxicity HNC $[\mu \mathrm{M}]^{\mathrm{C}}$} & \multirow[t]{2}{*}{$\mathrm{SI}^{\mathrm{d}}$} \\
\hline & & & Trypomastigote $\mathrm{CC}_{50}[\mu \mathrm{M}]^{\mathrm{a}} \mathrm{s}$ & Epimastigotes $\mathrm{CC}_{50}[\mu \mathrm{M}]^{\mathrm{b}}$ & & \\
\hline & & & & & & \\
\hline 2b & - & - & 2.5 & 15.4 & 21 & 8.4 \\
\hline $4 a$ & $\mathrm{Ph}$ & $\mathrm{H}$ & 6.3 & 93.4 & 51 & 8 \\
\hline $4 b$ & $\mathrm{Ph}$ & $\mathrm{Me}$ & 2.3 & 15.5 & 43 & 19 \\
\hline $4 c$ & $4-\mathrm{Ph}$ & $\mathrm{H}$ & 2.0 & 47.3 & 7 & 4 \\
\hline 4d & 4-OMePh & $\mathrm{H}$ & 1.2 & 5.0 & 477 & 398 \\
\hline $4 e$ & 4-FPh & $\mathrm{H}$ & 3.9 & 3.1 & 35 & 9 \\
\hline $4 \mathbf{f}$ & 4-ClPh & $\mathrm{H}$ & 2.0 & 9.1 & 13 & 7 \\
\hline $4 \mathrm{~g}$ & 4-BrPh & $\mathrm{H}$ & 1.8 & 6.3 & 10 & 6 \\
\hline $4 h$ & $4-\mathrm{NO}_{2} \mathrm{Ph}$ & $\mathrm{H}$ & 3.1 & 87.4 & 23 & 7 \\
\hline $4 i$ & $3-\mathrm{NO}_{2} \mathrm{Ph}$ & $\mathrm{H}$ & 1.9 & 11.0 & 10 & 5 \\
\hline $4 j$ & 3,4-diClPh & $\mathrm{H}$ & 1.9 & 13.9 & 8 & 4 \\
\hline $4 k$ & 2,4-diClPh & $\mathrm{H}$ & 1.6 & 2.7 & 81 & 51 \\
\hline 41 & 4-BrPh & $\mathrm{Me}$ & 3.1 & 17.1 & 30 & 10 \\
\hline $4 m$ & 2-Naph & $\mathrm{H}$ & 6.1 & 1.9 & 51 & 8 \\
\hline Bdz & - & - & 6.2 & 48.8 & 44.7 & 7.2 \\
\hline
\end{tabular}

$\mathrm{HNC}=$ highest non-cytotoxic concentration.

$\mathrm{Bdz}=$ benznidazole.

$\mathrm{ND}=$ not determined.

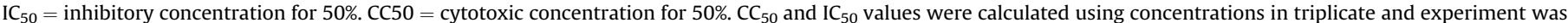
repeated, only values with a standard deviation $<10 \%$ mean were considered.

a Determined $24 \mathrm{~h}$ after incubation with compounds, using Y strain trypomastigotes.

b Determined 5 days after incubation with compounds, using Dm28c epimastigotes.

c Cell viability of J774A.1 macrophages determined $24 \mathrm{~h}$ after treatment.

d Selectivity index (SI) is the ratio of macrophages viability (HNC) to the $\mathrm{IC}_{50}$ on trypomastigotes.

The derivatives containing nitro group also showed high potency presenting $\mathrm{CC}_{50}$ values of 3.1 and $1.9 \mu \mathrm{M}$ for 4-nitrophenyl (4h) and 3-nitrophenyl (4i), respectively. Nitro substituent is a well-known antiparasitic pharmacophoric group [27-29] and in this work this activity was once again confirmed. Moreover, some potent compounds found here with electron-withdrawing substituents in phenyl attached in thiazole exhibit higher activity (3i, 3f, $4 \mathbf{i}$ and $\mathbf{4 f}$ ). These results are in accordance with a previous work which a CoMFA model built by HTS-ready assay that predicts the biological activity for similar molecules [29]. In contrast to the series 3a-m, both 4-biphenyl (4c) and 4-methoxyphenyl (4d) derivatives were potent trypanocidal agents with $\mathrm{CC}_{50}$ values of 2.0 and $1.2 \mu \mathrm{M}$, respectively, whereas 2 -naphthalene derivative (4m) caused a decrease in the trypanocidal activity, compared to other compounds in the series $4 \mathrm{a}-\mathrm{m}$, presenting $\mathrm{CC}_{50}$ value of $6.1 \mu \mathrm{M}$, however still equipotent to benznidazole. As the same manner in the series 3a-m, the insertion of methyl group attached to C4 of bromine derivatives did not influence the trypanocidal activity since 4-bromophenyl derivative ( $4 \mathrm{~g}$ ) has a CC50 value of $1.8 \mu \mathrm{M}$, whereas insertion of methyl group attached to $\mathrm{C} 4$ of thiazole generate the compound 41 with CC50 value of $3.1 \mu \mathrm{M}$. However, insertion of methyl group attached to $\mathrm{C} 4$ of nonsubstituted derivative (4a) with $\mathrm{CC}_{50}$ value of $6.3 \mu \mathrm{M}$ generate the compound $\mathbf{4 b}$ with $\mathrm{CC}_{50}$ value of $2.3 \mu \mathrm{M}$.

A trend toward trypanocidal potency with polar substituents on the phenyl was observed. These substituents led to some of the most potent thiazole variants examined, such as compounds $\mathbf{3 g}$ and $\mathbf{4 g}$ (4-bromine), $\mathbf{3 j}$ and $\mathbf{4 j}$ (3,4-dichloro), $\mathbf{3}$ and $\mathbf{4 i}$ (3-nitro), and $\mathbf{4 d}$ (4-methoxy). These results have been observed in thiazole derivatives of previous studies $[15,17,20]$.

Antiproliferative activity against epimastigotes was also verified for series $\mathbf{4 a - m}$. Excluding $\mathbf{4 a}$ and $\mathbf{4 h}$, all compounds were more active than benznidazole and able to inhibit epimastigote proliferation. Compounds $\mathbf{4 d}$ and $\mathbf{4 k}$, the most active against blood trypomastigote forms, were 10 and 18-times more potent than $\mathrm{Bdz}$, respectively, in inhibiting epimastigotes proliferation. Concerning cytotoxicity in macrophages, some of the thiazoles exhibited low cytotoxicity. For instance, compounds $\mathbf{4 b}, \mathbf{4 d}, \mathbf{4 e}, \mathbf{4 k}$ and 41 had $\mathrm{CC}_{50}<4.0 \mu \mathrm{M}$ against trypomastigotes, while they were non-toxic for macrophages at concentrations up to $30 \mu \mathrm{M}$. Selectivity indexes ( $\mathrm{SI}=\mathrm{CC}_{50}$ macrophage $/ \mathrm{CC}_{50}$ trypomastigote) were determined for compounds $\mathbf{4 b}, \mathbf{4 d}, \mathbf{4 e}, \mathbf{4 k}$ and $\mathbf{4 1}$, to be 19, 397, 9, 50 and 10, respectively. Likewise, thiazoles derivatives already were related as potent and selective inhibitors of $T$. cruzi besides showing absence of in vitro mutagenic and in vivo toxicity effects [16,17]. It is noteworthy that the compounds $\mathbf{4 d}$ and $\mathbf{4 k}$ presented SI values greater than 10 , then they can be considered candidates for new trypanocidal drugs being recommended for in vivo tests [25].

We also assayed the inhibitory activity for thiazoles (4a-m) against cruzain. Compounds were screened at $50 \mu \mathrm{M}$ and the maximum perceptual inhibition observed was 58 and $48 \%$ for compounds $\mathbf{4 e}$ and $\mathbf{4 d}$, respectively (data not shown). Despite 2(pyridin-2-yl)-1,3-thiazoles derivatives being potent anti-T. cruzi agents, it was not observed significant inhibition against cruzain as already observed for previously analogues 2-(pyridin-2-yl)-1,3thiazoles studied [20], suggesting that these compounds act in a different target than cruzain. However our findings can corroborate with previous data describing that 2-imino-1,3-thiazoles are trypanocidal agents by altering the ergosterol biosynthesis instead of inhibiting the catalytic activity of cruzain [30]. In sum, the bioisosterism strategy employed herein led to bioactive compounds more selective than the thiosemicarbazones of origin $\mathbf{2 a}$ and $\mathbf{2 b}$, SI of 2.5 and 8.4 respectively. The introduction of methyl and phenyl groups at $\mathrm{N} 3$ of thiazole ring provided some molecules more active than compounds without such substituents [20] as observed for other thiazole derivatives $[17,23]$. 
To understand the parasite death process caused by pyridin-2-yl derivatives, untreated and treated trypomastigotes were incubated for $24 \mathrm{~h}$ and then double labeled with annexin V-fluorescein isothiocyanate (FITC) and propidium iodide (PI) [31]. The most active compounds in each series ( $\mathbf{2 b}, \mathbf{3 g}, \mathbf{4 d}$ and $\mathbf{4 k}$ ) were selected for this assay and evaluated in concentrations equal to their $\mathrm{CC}_{50}$ and $\mathrm{CC}_{100}$. The data were acquired and analyzed by flow cytometry and results are show in Table 3 . In comparison to untreated parasites, treatment with pyridin-2-yl derivatives (2b, 3g, 4d and $\mathbf{4 k}$ ) decreased parasite cell viability. All compounds assayed were more efficient in inducing parasite cell death showing positively stained for PI, PI + FITC and FITC (Table 3). Parasite cells treated with compounds at their $\mathrm{CC}_{50}$ were approximately 10 times more positively stained for PI and PI + Annexin V and approximately 40 times more stained for Annexin V, when compared with the control. Parasites treated with the most active compound (4d) at $1.2 \mu \mathrm{M}$ presented $46.91 \%$ positively stained cells, of which $38.60 \%$ were early apoptotic (annexin V), 4.78\% were late apoptotic (PI + annexin V) and 3.53\% were necrotic (PI) (Fig. 2). Therefore, we suggest that pyridin-2-yl derivatives based treatment causes parasite cell death through apoptosis, suggesting that these compounds have more effects on cytoplasm and cell nucleus than in the cell membrane.

Finally we evaluated if the compounds synthesized that properties within the Lipinski's Rule of Five, which describes desired intervals for certain properties which are important for pharmacokinetics and drug development. Compound having at least three of the four criteria adheres to the Lipinski rule [32]. Other interest property is the polar surface area (PSA); since compounds with a low PSA $\left(\leq 140 \AA^{2}\right)$ tend to have higher oral bioavailability [33]. All compounds synthetized are compatible with Lipinski rule and present appropriate PSA (Table 4).

\section{Conclusions}

The 2-(pyridin-2-yl)-1,3-thiazoles were structurally designed by employing a molecular hybridization of the pyridine group with the heterocyclic ring thiazole associated with the non-classical bioisosterism strategy. This led to the synthesis and chemical characterization of compounds 3a-m and $\mathbf{4 a - m}$, which were evaluated their anti-T. cruzi, cytotoxicity and cruzain inhibition activities. The pharmacological evaluation led to the identification of potent and selective thiazoles (4d) and (4k) as anti-T. cruzi agents. Concerning their mechanism of action, these compounds did not inhibit cruzain and were observed to induce parasite cell death through an apoptotic process. The data argue that the strategies used are feasible to obtain novel potent and selective antiparasitic agents.

\section{Experimental section}

\subsection{General}

All reagents were used as purchased from commercial sources (Sigma-Aldrich, Acros Organics, Vetec or Fluka). Progress of the reactions was followed by thin-layer chromatography (silica gel 60 $\mathrm{F}_{254}$ in aluminum foil). Chemical identity was confirmed by NMR and IR spectroscopy and accurate mass. IR was determined in $\mathrm{KBr}$ pellets. For NMR, we used a Varian Unity Plus $400 \mathrm{MHz}(400 \mathrm{MHz}$ for ${ }^{1} \mathrm{H}$ and $100 \mathrm{MHz}$ for ${ }^{13} \mathrm{C}$ ) and Bruker AMX-300 MHz (300 MHz for ${ }^{1} \mathrm{H}$ and $75.5 \mathrm{MHz}$ for ${ }^{13} \mathrm{C}$ ) instruments. DMSO- $d_{6}$ and $\mathrm{CDCl}_{3}-d_{6}$ were purchased from CIL or Sigma-Aldrich. Chemical shifts are reported by ppm and multiplicities are given as: s (singlet), $\mathrm{d}$ (doublet), t (triplet), q (quartet), m (multiplet) integration, and coupling constants $(J)$ in hertz. Structural assignments corroborated by DEPT experiments. Mass spectrometry experiments were performed on a Q-TOF spectrometer (nanoUPLC-Xevo G2 Tof, Waters) or LC-IT-TOF (Shimadzu). When otherwise specified, ESI was carried out in the positive ion mode. Typical conditions were: capillary voltage of $3 \mathrm{kV}$ and cone voltage of $30 \mathrm{~V}$, and peak scan between 50 and $1000 \mathrm{~m} / \mathrm{z}$.

\subsection{General procedure for the synthesis of thiosemicarbazones (2a- b)}

To the solution of acetyl-2-pyridine $(0.9 \mathrm{~g}, 8 \mathrm{mmol})$ in ethanol $(15 \mathrm{~mL})$ was added 4-methyl-3-thiosemicarbazide (0.84 g, $7.98 \mathrm{mmol})$ or 4-phenyl-3-thiosemicarbazide ( $1.3 \mathrm{~g}, 8 \mathrm{mmol})$ and 5 drops of acetic acid. The reaction mixture was then maintained under stirring for $120 \mathrm{~min}$, at r. t. The precipitate was filtered off, washed with ethanol then dried in desiccator under vacuum. Additional amount of desired compound could be recovered from the filtrate after cooling.

\subsubsection{N-methyl-2-[1-(pyridin-2-yl)ethylidene]hydrazine-1- carbothioamide (2a)}

White crystals, yield: $94 \%$ M. p. $\left({ }^{\circ} \mathrm{C}\right): 172-174$. IR $\left(\mathrm{KBr}, \mathrm{cm}^{-1}\right)$ : 3287 and $3238(\mathrm{NH}), 1537(\mathrm{C}=\mathrm{N}) .{ }^{1} \mathrm{H}$ NMR (400 MHz, DMSO- $\left.d_{6}\right)$ : $\delta 2.38\left(\mathrm{~s}, 3 \mathrm{H}, \mathrm{CH}_{3}\right), 3.05\left(\mathrm{~d}, 3 \mathrm{H}, J=4.5 \mathrm{~Hz}, \mathrm{CH}_{3}\right), 7.37(\mathrm{t}, 1 \mathrm{H}, J=4.8$ and $11.1 \mathrm{~Hz}, \mathrm{CH}$, thiazole), $7.81(\mathrm{t}, 1 \mathrm{H}, J=7.5$ and $17.1 \mathrm{~Hz}, \mathrm{CH}$, Heterocycle), $8.42(\mathrm{~d}, 1 \mathrm{H}, J=8.4 \mathrm{~Hz}, \mathrm{CH}$, Heterocycle), $8.60(\mathrm{~m}, 2 \mathrm{H}, \mathrm{NH}$, $\mathrm{CH}$, Heterocycle), $10.36(\mathrm{~s}, 1 \mathrm{H}, \mathrm{NH}) .{ }^{13} \mathrm{C}$ NMR (75.5 MHz, DMSO- $\left.d_{6}\right)$ : $12.1\left(\mathrm{CH}_{3}\right), 31.2\left(\mathrm{CH}_{3}\right), 120.8(\mathrm{CH}$, Heterocycle $), 123.9(\mathrm{CH}, \mathrm{Ar}), 136.3$ ( $\mathrm{CH}$, Heterocycle), $147.8(\mathrm{Cq}=\mathrm{N}), 148.4(\mathrm{Cq}-\mathrm{N}$, Heterocycle), 154.7 (Cq-N, Heterocycle), $178.7(\mathrm{Cq})$.

Table 3

Analysis of parasite death process caused by 2-(pyridin-2-yl)-1,3-thiazoles derivatives.

\begin{tabular}{|c|c|c|c|c|}
\hline Compd. & Concentration $(\mu \mathrm{M})$ & \% PI- positively stained cells ${ }^{\mathrm{a}}$ & $\% \mathrm{PI}$ and annexin V double positively stained cells ${ }^{\mathrm{a}}$ & $\%$ Annexin V positively stained cells ${ }^{\mathrm{a}}$ \\
\hline Triton $X-100(10 \mu L)$ & - & 67.8 & & $<10$ \\
\hline Bdz & 5.0 & 4.2 & & \\
\hline Bdz & 25 & 56.4 & & \\
\hline 2b & 2.5 & 3.6 & 5.4 & 36.8 \\
\hline $\mathbf{2 b}$ & 5.0 & 3.55 & 4.8 & 36 \\
\hline $3 g$ & 2.2 & 3 & 4 & 38 \\
\hline $3 g$ & 4.4 & 3.15 & 4.7 & 35 \\
\hline 4d & 1.2 & 3.5 & 4.8 & 38.6 \\
\hline 4d & 2.4 & 2.9 & 4.5 & 36.4 \\
\hline $4 k$ & 1.6 & 2.9 & 4 & 39.5 \\
\hline $4 k$ & 3.2 & 3.2 & 4.3 & 39.4 \\
\hline
\end{tabular}

\footnotetext{
${ }^{\text {a }}$ Values were taken from two different readings of at least 10,000 events $24 \mathrm{~h}$ after incubation with Y strain trypomastigotes.
} 
untreated

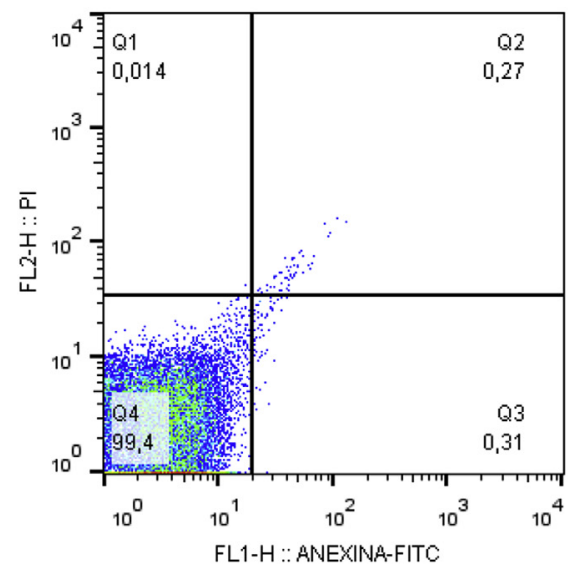

(4d), $1.2 \mu \mathrm{M}$

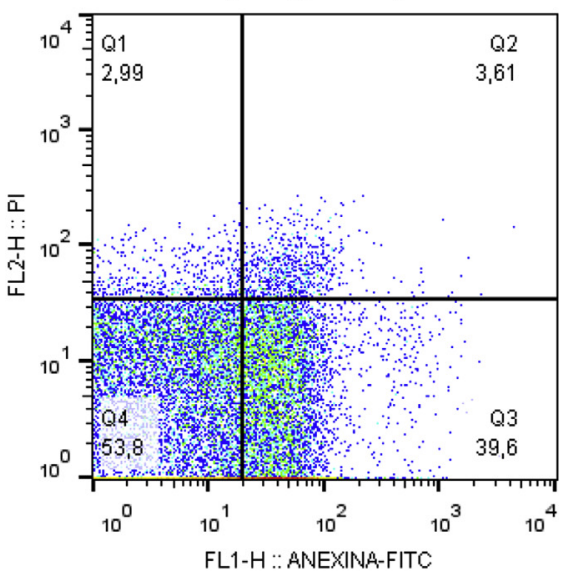

(4d), $2.4 \mu M$

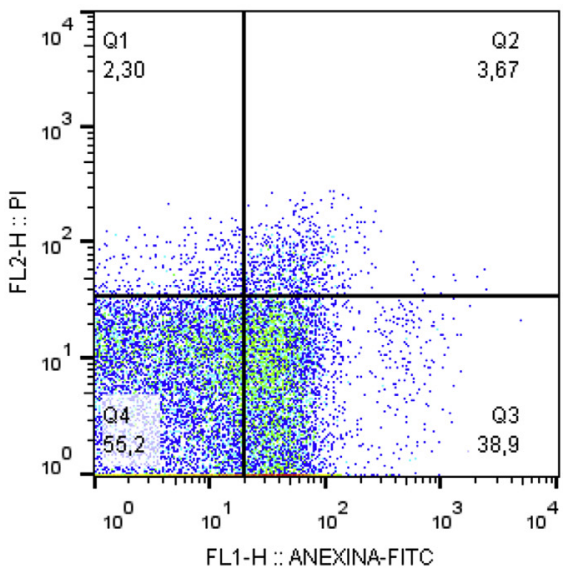

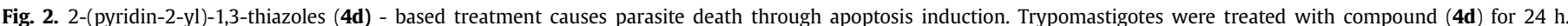

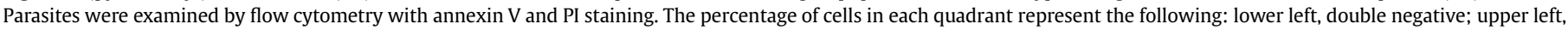
$\mathrm{PI}$ single positive; lower right, annexin $\mathrm{V}$ single positive; upper right, PI and annexin $\mathrm{V}$ double positive.

Table 4

Physicochemical properties calculated for the most potent 2-(pyridin-2-yl)-1,3-thiazoles.

\begin{tabular}{|c|c|c|c|c|c|c|}
\hline Compd. & $\mathrm{MW}$ (g/mol) & $\mathrm{C} \log \mathrm{P}$ & $\mathrm{H}$ bond donos & $\mathrm{H}$ bond acceptors & Criteria met & $\operatorname{PSA}\left(\AA^{2}\right)$ \\
\hline Desirable value & $<500$ & $<5$ & $<5$ & $<10$ & 3 at least & $\leq 140$ \\
\hline $3 g$ & 386.02 & 3.57 & 0 & 4 & All & 40.85 \\
\hline $3 \mathbf{j}$ & 376.03 & 4.01 & 0 & 4 & All & 40.85 \\
\hline 4d & 400.13 & 4.31 & 0 & 5 & All & 50.08 \\
\hline $4 \mathrm{~g}$ & 448.03 & 5.24 & 0 & 4 & 3 & 40.85 \\
\hline $4 i$ & 415.11 & 4.41 & 0 & 6 & All & 86.67 \\
\hline $4 k$ & 438.04 & 5.68 & 0 & 4 & 3 & 40.85 \\
\hline
\end{tabular}

4.2.2. N-phenyl-2-[1-(pyridin-2-yl)ethylidene]hydrazine-1carbothioamide $(2 b)$

White crystals, yield: $89 \%$. M. p. $\left({ }^{\circ} \mathrm{C}\right): 182-184 . \mathrm{IR}\left(\mathrm{KBr}, \mathrm{cm}^{-1}\right)$ : 3299 and $3240(\mathrm{NH}), 1522(\mathrm{C}=\mathrm{N}) .{ }^{1} \mathrm{H}$ NMR (400 MHz, DMSO- $\left.d_{6}\right)$ : $\delta 2.87\left(\mathrm{~s}, 3 \mathrm{H}, \mathrm{CH}_{3}\right), 7.63(\mathrm{t}, 1 \mathrm{H}, J=7.8$ and $14.7 \mathrm{~Hz}, \mathrm{CH}, \mathrm{Ar}), 7.79(\mathrm{~m}$, $3 \mathrm{H}, \mathrm{CH}$ Ar, CH Ar, CH Heterocycle), 7.95 (d, 2H, $J=7.8 \mathrm{~Hz}, \mathrm{CH}$ Ar, $\mathrm{CH}$ $\mathrm{Ar}), 8.21(\mathrm{t}, 1 \mathrm{H}, J=7.8$ and $14.7 \mathrm{~Hz}, \mathrm{CH}$, Heterocycle), 8.95 (d, $1 \mathrm{H}$, $J=7.8 \mathrm{~Hz}, \mathrm{CH}$, Heterocycle), 9.00 (d, $1 \mathrm{H}, J=4.2 \mathrm{~Hz}, \mathrm{CH}-\mathrm{N}$, Heterocycle), 10.61 (s, $1 \mathrm{H}, \mathrm{NH}), 11.10(\mathrm{~s}, 1 \mathrm{H}, \mathrm{NH}) .{ }^{13} \mathrm{C}$ NMR $(75.5 \mathrm{MHz}$, DMSO- $\left.d_{6}\right): \delta 12.5\left(\mathrm{CH}_{3}\right), 121.2(\mathrm{CH}, \mathrm{Ar}), 124.1(\mathrm{CH}, \mathrm{Ar}), 125.6(\mathrm{CH}, \mathrm{Ar})$, 126.2 (CH, Ar), 128.1 (CH, Ar), $136.4(\mathrm{CH}, \mathrm{Ar}), 139.1(\mathrm{CH}, \mathrm{Ar}), 148.5$ $(\mathrm{Cq}=\mathrm{N}), 149.2(\mathrm{Cq}-\mathrm{N}, \mathrm{Ar}), 154.5(\mathrm{Cq}-\mathrm{N}, \mathrm{Ar}), 177.3(\mathrm{Cq}=\mathrm{S})$. HRMS (ESI): $271.148[\mathrm{M}+\mathrm{H}]$.

4.3. General procedure for the synthesis of 2-imino-1,3-thiazoles $3 a-m$ and $4 a-m$. example for compound $3 a$

2-bromoacetophenone (0.47 $\mathrm{g}, 2.4 \mathrm{mmol})$ dissolved in 2propanol $(15 \mathrm{~mL})$ was placed in an ultrasound bath $(40 \mathrm{MHz}$, $180 \mathrm{~V})$. Then thiosemicarbazone $\mathbf{2 a}(0.5 \mathrm{~g}, 2.3 \mathrm{mmol})$ was added to the mixture and kept until the consumption of the starting materials (60 $\mathrm{min}$ ). The reaction was cooled and the colorful precipitate was separated in funnel with sintered disc filter and washed with cold 2-propanol, and then dried in $\mathrm{SiO}_{2}$ glass dissector under vacuum. Most of the compounds were shown to be pure in thin layer chromatography. For the compounds 3d, 3e, 3f, 3g, 3h, 3i, 3j, 3l, 4b, 4e, $4 h, 4 i, 41$ and $4 m$ were recrystallized from hot ethanol.
4.3.1. $\mathrm{N}$-(4-phenyl-3-methyl-3H-thiazol-2-ylidene)-N'-(1-pyridin2-yl-ethylidene)-hydrazine ( $3 a$ )

Reddish crystals, yield: $85 \%$ (. M. p. $\left({ }^{\circ} \mathrm{C}\right)$ : 204-206. IR ( $\mathrm{KBr}$, $\left.\mathrm{cm}^{-1}\right)$ : 1581 and $1555(\mathrm{C}=\mathrm{N}), 1491(\mathrm{C}=\mathrm{C}) .{ }^{1} \mathrm{H}$ NMR $(400 \mathrm{MHz}$, DMSO- $\left.d_{6}\right): \delta 2.45\left(\mathrm{~s}, 3 \mathrm{H}, \mathrm{CH}_{3}\right), 3.43\left(\mathrm{~s}, 3 \mathrm{H}, \mathrm{N}-\mathrm{CH}_{3}\right), 6.69(\mathrm{~s}, 1 \mathrm{H}, \mathrm{CH}$, Thiazole), $7.52(\mathrm{~m}, 5 \mathrm{H}, \mathrm{CH}, \mathrm{Ar}), 7.77(\mathrm{t}, 1 \mathrm{H}, J=4.0$ and $12.0 \mathrm{~Hz}, \mathrm{CH}$, Heterocycle), 8.27 (d, $1 \mathrm{H}, J=8.0 \mathrm{~Hz}, \mathrm{CH}$, Heterocycle), $8.38(\mathrm{t}, 1 \mathrm{H}$, $J=8.0$ and $12.0 \mathrm{~Hz}, \mathrm{CH}$, Heterocycle), $8.71(\mathrm{~d}, 1 \mathrm{H}, J=4.0 \mathrm{~Hz}, \mathrm{CH}=\mathrm{N}$, Heterocycle). ${ }^{13} \mathrm{C}$ NMR and DEPT (100 MHz, DMSO- $\left.d_{6}\right): 13.1\left(\mathrm{CH}_{3}\right)$, $34.0\left(\mathrm{CH}_{3}\right), 102.3(\mathrm{CH}$, thiazole $), 123.1(\mathrm{CH}), 124.8(\mathrm{CH}), 128.88(2 \mathrm{CH}$, $\mathrm{Ar}), 128.91(\mathrm{CH}$, Heterocycle), $129.5(\mathrm{CH}$, Heterocycle), $130.0(\mathrm{Cq})$, 141.1 (Cq, Heterocycle), $143.8(\mathrm{CH}=\mathrm{N}$, Heterocycle), $150.4(\mathrm{Cq})$, 172.3 (Cq). HRMS (ESI): 309.14 [M+H].

4.3.2. $N$-(5-methyl-4-methyl-3-phenyl-3H-thiazol-2-ylidene)-N'-

(1-pyridin-2-yl-ethylidene)-hydrazine (3b)

Reddish crystals, yield: $40 \%$. M. p. $\left({ }^{\circ} \mathrm{C}\right): 234-236$. IR $\left(\mathrm{KBr}, \mathrm{cm}^{-1}\right)$ : 1523 and $1495(\mathrm{C}=\mathrm{N}), 1464(\mathrm{C}=\mathrm{C}) .{ }^{1} \mathrm{H}$ NMR $\left(300 \mathrm{MHz}\right.$, DMSO- $\left.d_{6}\right)$ : $\delta 2.06,2.45$ and 2.49 (s, 3H, $\left.\mathrm{CH}_{3}\right), 7.46(\mathrm{~m}, 2 \mathrm{H}, \mathrm{CH}, \mathrm{Ar}), 7.56(\mathrm{~m}, 3 \mathrm{H}$, $\mathrm{CH}, \mathrm{Ar}), 7.75(\mathrm{t}, 1 \mathrm{H}, J=6.0$ and $12.6 \mathrm{~Hz}, \mathrm{CH}$, Heterocycle), $8.27(\mathrm{~d}, 1 \mathrm{H}$, $J=8.1 \mathrm{~Hz}, \mathrm{CH}$, Heterocycle), $8.35(\mathrm{t}, 1 \mathrm{H}, J=8.1$ and $15.0 \mathrm{~Hz}, \mathrm{CH}$, Heterocycle), $8.70\left(\mathrm{~d}, 1 \mathrm{H}, J=5.1 \mathrm{~Hz}, \mathrm{CH}=\mathrm{N}\right.$, Heterocycle). ${ }^{13} \mathrm{C} \mathrm{NMR}$ and DEPT (75.5 MHz, DMSO- $\left.d_{6}\right): 12.0\left(\mathrm{CH}_{3}\right) ; 13.1\left(\mathrm{CH}_{3}\right) ; 34.1\left(\mathrm{CH}_{3}\right)$; $112.0(\mathrm{CH}$, thiazole); $123.4(\mathrm{CH}, \mathrm{Ar}) ; 125.3(\mathrm{CH}, \mathrm{Ar}) ; 129.3(\mathrm{CH}, \mathrm{Ar})$; 129.4 (CH, Heterocycle); $129.9(\mathrm{Cq}) ; 130.0(\mathrm{CH}$, Heterocycle); 136.2 (Cq); $144.4(\mathrm{CH}$, Heterocycle); 170.9 (CH, Heterocycle). HRMS (ESI): $322.12[\mathrm{M}-\mathrm{H}]$. 
4.3.3. $N$-\{[4-(1,1'-biphenyl)-4-yl]-3-methyl-3H-thiazol-2-ylidene $\}$ -

$N^{\prime}$-(1-pyridin-2-yl-ethylidene)-hydrazine (3c)

Reddish crystals, yield: $53 \%$. M. p. $\left({ }^{\circ} \mathrm{C}\right)$ : $111-114$. IR $\left(\mathrm{KBr}, \mathrm{cm}^{-1}\right)$ : $1599(\mathrm{C}=\mathrm{N}), 1481(\mathrm{C}=\mathrm{C}) .{ }^{1} \mathrm{H}$ NMR (300 MHz, DMSO-d $): \delta 2.22$ and $2.48\left(\mathrm{~s}, 3 \mathrm{H}, \mathrm{CH}_{3}\right), 6.91(\mathrm{~s}, 1 \mathrm{H}, \mathrm{CH}$ of thiazole), $7.39(\mathrm{~m}, 5 \mathrm{H}, \mathrm{CH}, \mathrm{Ar})$, 7.59 ( $\mathrm{m}, 4 \mathrm{H}, \mathrm{CH}, \mathrm{Ar}), 7.69$ (t, 1H, CH, Heterocycle), $8.24(\mathrm{~m}, 2 \mathrm{H}, \mathrm{CH}$, Heterocycle), $8.68\left(\mathrm{~d}, 1 \mathrm{H}, \mathrm{J}=4.5 \mathrm{~Hz}, \mathrm{CH}=\mathrm{N}\right.$, Heterocycle). ${ }^{13} \mathrm{C} \mathrm{NMR}$ and DEPT (75.5 MHz, DMSO- $\left.d_{6}\right): 13.8\left(\mathrm{CH}_{3}\right), 21.3\left(\mathrm{CH}_{3}\right), 103.9(\mathrm{CH}$, Thiazole), 107.7 (CH, Ar), 124.2 ( $\mathrm{CH}, \mathrm{Ar}), 125.2(\mathrm{CH}, \mathrm{Ar}), 126.8(\mathrm{CH}$, $\mathrm{Ar}), 127.0(\mathrm{CH}, \mathrm{Ar}), 128.9$ ( $\mathrm{CH}$, Heterocycle), 129.3 ( $\mathrm{CH}$, Heterocycle), $129.4(\mathrm{CH}$, Heterocycle), $137.8(\mathrm{CH}=\mathrm{N}$, Heterocycle), $139.3(\mathrm{Cq}$, Heterocycle), 140.5 (Cq), 145.4 (Cq). HRMS (ESI): 384.08 [M - H].

4.3.4. $\mathrm{N}$-[4-(4-methoxy-phenyl)-3-methyl-3H-thiazol-2-ylidene]$N^{\prime}$-(1-pyridin-2-yl-ethylidene)-hydrazine (3d)

Recrystallization from ethanol afforded reddish crystals, yield: 38\%. M. p. $\left({ }^{\circ} \mathrm{C}\right)$ : $153-156$. IR $\left(\mathrm{KBr}, \mathrm{cm}^{-1}\right): 1588$ and $1521(\mathrm{C}=\mathrm{N})$, $1420(\mathrm{C}=\mathrm{C}), 1251(\mathrm{C}-\mathrm{O}-\mathrm{C}) .{ }^{1} \mathrm{H}$ NMR $\left(300 \mathrm{MHz}, \mathrm{DMSO}-d_{6}\right): \delta 2.43$ (s, $\left.3 \mathrm{H}, \mathrm{CH}_{3}\right), 3.34\left(\mathrm{~s}, 3 \mathrm{H}, \mathrm{CH}_{3}-\mathrm{N}\right), 3.81\left(\mathrm{~s}, 3 \mathrm{H}, \mathrm{CH}_{3}-\mathrm{O}\right), 6.35(\mathrm{~s}, 1 \mathrm{H}, \mathrm{CH}$ of thiazole), 7.05 (d, 2H, CH, Ar), $7.39(\mathrm{~m}, 3 \mathrm{H}, \mathrm{CH}, \mathrm{Ar}), 7.80(\mathrm{~d}, 1 \mathrm{H}, \mathrm{CH}$, Heterocycle), $8.09(\mathrm{t}, 1 \mathrm{H}, \mathrm{CH}$, Heterocycle $), 8.57(\mathrm{~d}, 1 \mathrm{H}, \mathrm{CH}$, Heterocycle). ${ }^{13} \mathrm{C}$ NMR and DEPT (75.5 MHz, DMSO- $\left.d_{6}\right): 12.9\left(\mathrm{CH}_{3}\right), 33.3$ $\left(\mathrm{CH}_{3}-\mathrm{N}_{3}\right), 55.2\left(\mathrm{CH}_{3}-\mathrm{O}, \mathrm{Ar}\right), 99.2(\mathrm{CH}$, thiazole $), 114.1(2 \mathrm{CH}, \mathrm{Ar}), 119.6$ $(\mathrm{CH}, \mathrm{Ar}), 122.6(\mathrm{Cq}, \mathrm{Ar}), 123.0(\mathrm{CH}, \mathrm{Ar}), 130.1(\mathrm{CH}, \mathrm{Ar}), 136.0(\mathrm{CH}, \mathrm{Ar})$, $140.4(\mathrm{CH}-\mathrm{N}, \mathrm{Ar}), 148.4(\mathrm{CH}=\mathrm{N}$, Heterocycle), 154.9 (Cq-N, Heterocycle), 156.0 (Cq-O, $\mathrm{Ar}), 159.8(\mathrm{Cq}=\mathrm{N}), 169.9(\mathrm{Cq})$. HRMS (ESI): $339.17[\mathrm{M}+\mathrm{H}]$.

4.3.5. $\mathrm{N}$-[4-(4-fluor-phenyl)-3-methyl-3H-thiazol-2-ylidene]-N'-

(1-pyridin-2-yl-ethylidene)-hydrazine (3e)

Recrystallization from ethanol afforded yellowish crystals, yield: 32\%. M. p. $\left({ }^{\circ} \mathrm{C}\right): 174-176 . \mathrm{IR}\left(\mathrm{KBr}, \mathrm{cm}^{-1}\right): 1583$ and $1520(\mathrm{C}=\mathrm{N}), 1419$ $(\mathrm{C}=\mathrm{C}) .{ }^{1} \mathrm{H}$ NMR $\left(400 \mathrm{MHz}, \mathrm{DMSO}-d_{6}\right): \delta 2.42\left(\mathrm{~s}, 3 \mathrm{H}, \mathrm{CH}_{3}\right), 3.35(\mathrm{~s}$, $\left.3 \mathrm{H}, \mathrm{CH}_{3}\right), 6.46(\mathrm{~s}, 1 \mathrm{H}, \mathrm{CH}$, Thiazole $), 7.33(\mathrm{~m}, 4 \mathrm{H}, \mathrm{CH}, \mathrm{Ar}), 7.58(\mathrm{t}, 1 \mathrm{H}$, $J=3.0$ and $12.0 \mathrm{~Hz}, \mathrm{CH}$, Heterocycle), $7.80(\mathrm{t}, 1 \mathrm{H}, J=6.0$ and $12.0 \mathrm{~Hz}$, $\mathrm{CH}$, Heterocycle), 8.09 (d, $1 \mathrm{H}, J=6.0 \mathrm{~Hz}, \mathrm{CH}$, Heterocycle), 8.56 (d, $1 \mathrm{H}, J=3.0 \mathrm{~Hz}, \mathrm{CH}=\mathrm{N}$, Heterocycle). ${ }^{13} \mathrm{C}$ NMR and DEPT $(100 \mathrm{MHz}$, DMSO-d $\left.d_{6}\right): 13.1\left(\mathrm{CH}_{3}\right), 33.5\left(\mathrm{~N}-\mathrm{CH}_{3}\right), 100.5(\mathrm{CH}$, Thiazole $), 115.7(\mathrm{CH}$, $\mathrm{Ar}), 115.9(\mathrm{CH}, \mathrm{Ar}), 119.8$ (CH, Ar), $123.3(\mathrm{CH}, \mathrm{Ar}), 126.9$ (C, Ar), 131.1 $(\mathrm{CH}, \mathrm{Ar}), 131.2(\mathrm{CH}, \mathrm{Ar}), 136.2(\mathrm{CH}, \mathrm{Ar}), 139.6(\mathrm{C}, \mathrm{Ar}), 148.6(\mathrm{C}=\mathrm{N}$, Heterocycle), 155.2 (C-N, Heterocycle), $156(C=N), 161.3(C-F, A r)$, 170 (N-C-S). HRMS (ESI): 325.19 [M+H].

4.3.6. $\mathrm{N}$-[4-(4-chloro-phenyl)-3-methyl-3H-thiazol-2-ylidene]-N'-

(1-pyridin-2-yl-ethylidene)-hydrazine ( $3 f$ )

Recrystallization from ethanol afforded yellowish crystals, yield: 39\%. M. p. $\left({ }^{\circ} \mathrm{C}\right)$ : $154-156$. IR $\left(\mathrm{KBr}, \mathrm{cm}^{-1}\right): 1584$ and $1558(\mathrm{C}=\mathrm{N})$, $1463(\mathrm{C}=\mathrm{C}) .{ }^{1} \mathrm{H}$ NMR $\left(400 \mathrm{MHz}\right.$, DMSO- $\left.d_{6}\right): \delta 2.44\left(\mathrm{~s}, 3 \mathrm{H}, \mathrm{CH}_{3}\right), 3.37$ $\left(\mathrm{s}, 3 \mathrm{H}, \mathrm{N}-\mathrm{CH}_{3}\right), 6.50(\mathrm{~s}, 1 \mathrm{H}, \mathrm{CH}$ Thiazole), $7.36(\mathrm{t}, 1 \mathrm{H}, J=6.0$ and $12.0 \mathrm{~Hz}, \mathrm{CH}, \mathrm{Ar}), 7.56(\mathrm{~m}, 4 \mathrm{H}, \mathrm{CH}, \mathrm{Ar}), 7.84(\mathrm{t}, 1 \mathrm{H}, J=7.6$ and $12.0 \mathrm{~Hz}$, $\mathrm{CH}$, Heterocycle), 8.11 (d, $1 \mathrm{H}, J=8.0 \mathrm{~Hz}, \mathrm{CH}$, Heterocycle), 8.58 (d, $1 \mathrm{H}, J=6.8 \mathrm{~Hz}, \mathrm{CH}=\mathrm{N}$, Heterocycle $).{ }^{13} \mathrm{C}$ NMR and DEPT $(100 \mathrm{MHz}$, DMSO- $\left.d_{6}\right): 13.0\left(\mathrm{CH}_{3}\right), 33.4\left(\mathrm{~N}-\mathrm{CH}_{3}\right), 101.0(\mathrm{CH}$, Thiazole $), 120.0$ (2CH, Ar), 123.2 (2CH, Ar), 128.7 (CH, Ar), 129.2 (CH, Ar), $130.4(\mathrm{C}$, $\mathrm{Ar}), 133.9(\mathrm{CH}, \mathrm{Ar}), 136.5(\mathrm{C}-\mathrm{Cl}), 139.4(\mathrm{C}, \mathrm{Ar}), 148.1$ (C=N, Heterocycle), 154.8 (C-N, Heterocycle), $155.6(\mathrm{C}=\mathrm{N}), 170.0(\mathrm{~N}-\mathrm{C}-\mathrm{S}, \mathrm{Ar})$. HRMS (ESI): 343.082 [M - H].

\subsection{7. $\mathrm{N}$-[4-(4-bromo-phenyl)-3-methyl-3H-thiazol-2-ylidene]-N'-}

(1-pyridin-2-yl-ethylidene)-hydrazine (3 g)

Recrystallization from ethanol afforded reddish crystals, yield: 54\%. M. p. $\left({ }^{\circ} \mathrm{C}\right): 160-162$. IR $\left(\mathrm{KBr}, \mathrm{cm}^{-1}\right): 1583$ and $1525(\mathrm{C}=\mathrm{N})$, $1420(\mathrm{C}=\mathrm{C}) .{ }^{1} \mathrm{H}$ NMR $\left(300 \mathrm{MHz}, \mathrm{DMSO}-\mathrm{d}_{6}\right): \delta 2.44\left(\mathrm{~s}, 3 \mathrm{H}, \mathrm{CH}_{3}\right), 3.37$ $\left(\mathrm{s}, 3 \mathrm{H}, \mathrm{N}-\mathrm{CH}_{3}\right), 6.54(\mathrm{~s}, 1 \mathrm{H}, \mathrm{CH}$, Thiazol), $7.46(\mathrm{~m}, 3 \mathrm{H}, \mathrm{CH}, \mathrm{Ar}), 7.70$ (d, $2 \mathrm{H}, \mathrm{CH}, \mathrm{Ar}), 7.89$ (d, 1H, CH, Heterocycle), $8.12(\mathrm{~d}, 1 \mathrm{H}, \mathrm{CH}$,
Heterocycle), 8.42 (t, 1H, CH, Heterocycle), 8.59 (d, 1H, CH, Heterocycle). ${ }^{13} \mathrm{C}$ NMR and DEPT (75 MHz, DMSO- $\left.d_{6}\right): 13.1\left(\mathrm{CH}_{3}\right), 33.6$ $\left(\mathrm{N}-\mathrm{CH}_{3}\right), 101.3(\mathrm{CH}$, Thiazole), $120.2(\mathrm{CH}, \mathrm{Ar}), 122.6(\mathrm{C}, \mathrm{Ar}), 123.5(\mathrm{CH}$, Ar), 124.0 (CH, Ar), 129.5 (Cq-N,Ar), 130.8 (CH, Ar), 131.7 (CH, Ar), 137.2 $(\mathrm{CH}, \mathrm{Ar}), 139.6(\mathrm{C}=\mathrm{N}$, Heterocycle $), 147.8(\mathrm{C}=\mathrm{N}), 155.0(\mathrm{~N}-\mathrm{C}-$ S). HRMS (ESI): 387.063 [M - H].

\subsubsection{N-[4-(4-nitro-phenyl)-3-methyl-3H-thiazol-2-ylidene]-N'-}

(1-pyridin-2-yl-ethylidene)-hydrazine (3 h)

Recrystallization from ethanol afforded yellowish crystals, yield: 43\%. M. p. $\left({ }^{\circ} \mathrm{C}\right): 200-203$. IR $\left(\mathrm{KBr}, \mathrm{cm}^{-1}\right): 1598$ and $1564(\mathrm{C}=\mathrm{N})$, $1462(\mathrm{C}=\mathrm{C}), 1344\left(\mathrm{NO}_{2}\right) .{ }^{1} \mathrm{H}$ NMR $\left(300 \mathrm{MHz}, \mathrm{DMSO}-d_{6}\right): \delta 2.45(\mathrm{~s}$, $\left.3 \mathrm{H}, \mathrm{CH}_{3}\right), 3.42\left(\mathrm{~s}, 3 \mathrm{H}, \mathrm{N}-\mathrm{CH}_{3}\right), 6.75(\mathrm{~s}, 1 \mathrm{H}, \mathrm{CH}$, Thiazole $), 7.38(\mathrm{t}, 1 \mathrm{H}$, $\mathrm{CH}, \mathrm{Ar}), 7.83(\mathrm{~m}, 3 \mathrm{H}, \mathrm{CH}, \mathrm{Ar}), 8.11(\mathrm{~d}, 1 \mathrm{H}, \mathrm{CH}$, Heterocycle), $8.33(\mathrm{t}$, $2 \mathrm{H}, \mathrm{CH}$, Heterocycle), $8.59\left(\mathrm{~d}, 1 \mathrm{H}, \mathrm{CH}=\mathrm{N}\right.$, Heterocycle). ${ }^{13} \mathrm{C} \mathrm{NMR}$ (75.5 MHz, DMSO- $\left.d_{6}\right)$ : $18.4\left(\mathrm{CH}_{3}\right), 39.1\left(\mathrm{~N}-\mathrm{CH}_{3}\right), 108.8(\mathrm{CH}$, Thiazole), $125.2(\mathrm{CH}, \mathrm{Ar}), 128.7(\mathrm{CH}, \mathrm{Ar}), 129.1(\mathrm{CH}, \mathrm{Ar}), 135.0(\mathrm{C}, \mathrm{Ar})$, 141.8 (Cq, Ar), $144.1\left(C-\mathrm{NO}_{2}\right), 152.7(\mathrm{C}=\mathrm{N}$, Heterocycle), $153.5(C-\mathrm{N}$, Heterocycle), $160.9(\mathrm{C}=\mathrm{N}), 175.3(\mathrm{~N}-\mathrm{C}-\mathrm{S})$. HRMS (ESI): 354.10 $[\mathrm{M}+\mathrm{H}]$.

\subsection{9. $\mathrm{N}$-[4-(3-nitro-phenyl)-3-methyl-3H-thiazol-2-ylidene]- $N^{\prime}-$ (1-pyridin-2-yl-ethylidene)-hydrazine (3i)}

Recrystallization from ethanol afforded orange crystals, yield: 93\%. M. p. $\left({ }^{\circ} \mathrm{C}\right): 242-244$. IR $\left(\mathrm{KBr}, \mathrm{cm}^{-1}\right): 1588$ and $1533(\mathrm{C}=\mathrm{N})$, $1486(\mathrm{C}=\mathrm{C}), 1352\left(\mathrm{NO}_{2}\right) .{ }^{1} \mathrm{H}$ NMR $\left(300 \mathrm{MHz}, \mathrm{DMSO}-d_{6}\right): \delta 2.23$ and $2.48\left(\mathrm{~s}, 3 \mathrm{H}, \mathrm{CH}_{3}\right), 7.16(\mathrm{~s}, 1 \mathrm{H}, \mathrm{CH}$, Thiazole), 7.57 ( $\mathrm{m}, 3 \mathrm{H}, \mathrm{CH}, \mathrm{Ar}), 7.79$ $(\mathrm{s}, 1 \mathrm{H}, \mathrm{CH}, \mathrm{Ar}), 8.06(\mathrm{~d}, 1 \mathrm{H}, J=24.0 \mathrm{~Hz}, \mathrm{CH}$, Heterocycle $), 8.32(\mathrm{~m}, 2 \mathrm{H}$, $\mathrm{CH}$, Heterocycle), 8.72 (d, 1H, CH, Heterocycle). ${ }^{13} \mathrm{C}$ NMR $(75.5 \mathrm{MHz}$, DMSO- $\left.d_{6}\right)$ : $13.9\left(\mathrm{CH}_{3}\right), 106.2(\mathrm{CH}$, Thiazole $), 123.5(\mathrm{CH}, \mathrm{Ar}), 123.6$ ( $\mathrm{CH}, \mathrm{Ar}), 123.8(\mathrm{CH}, \mathrm{Ar}), 125.7(\mathrm{CH}, \mathrm{Ar}), 128.9(\mathrm{CH}, \mathrm{Ar}), 129.5(\mathrm{CH}, \mathrm{Ar})$, 130.4 (CH, Ar), 132.2 ( $\mathrm{CH}, \mathrm{Ar}), 135.2(\mathrm{CH}, \mathrm{Ar}), 137.2$ ( $\mathrm{CH}$, Heterocycle), $138.2(\mathrm{CH}$, Heterocycle), $143.9(\mathrm{CH}=\mathrm{N}$, Heterocycle $), 144.5(\mathrm{CH}$, Heterocycle), 147.9 (Cq, Heterocycle), 150.7 (Cq), 172.5 (Cq). HRMS (ESI): 352.85 [M - H].

\subsubsection{0. $N$-[4-(3,4-dichloro-phenyl)-3-methyl-3H-thiazol-2-}

ylidene]-N'-(1-pyridin-2-yl-ethylidene)-hydrazine (3j)

Recrystallization from ethanol afforded orange crystals, yield: 83\%. M. p. $\left({ }^{\circ} \mathrm{C}\right)$ : $195-197 . \mathrm{IR}\left(\mathrm{KBr}, \mathrm{cm}^{-1}\right): 1595$ and $1526(\mathrm{C}=\mathrm{N})$, $1492(\mathrm{C}=\mathrm{C}) .{ }^{1} \mathrm{H}$ NMR $\left(300 \mathrm{MHz}, \mathrm{CHCl}_{3}-d_{6}\right): \delta 2.59\left(\mathrm{~s}, 3 \mathrm{H}, \mathrm{CH}_{3}\right), 3.43$ $\left(\mathrm{s}, 3 \mathrm{H}, \mathrm{CH}_{3}\right), 6.24(\mathrm{~s}, 1 \mathrm{H}, \mathrm{CH}$, Thiazole $), 7.21(\mathrm{~d}, 1 \mathrm{H}, J=2.4 \mathrm{~Hz}, \mathrm{CH}, \mathrm{Ar})$, $7.44(\mathrm{~d}, 1 \mathrm{H}, J=1.8 \mathrm{~Hz}, \mathrm{CH}, \mathrm{Ar}), 7.18(\mathrm{~d}, 1 \mathrm{H}, J=8.4 \mathrm{~Hz}, \mathrm{CH}, \mathrm{Ar}), 7.61(\mathrm{~m}$ $1 \mathrm{H}, \mathrm{CH}$, Heterocycle), 8.20 ( $\mathrm{m}, 2 \mathrm{H}, \mathrm{CH}$, Heterocycle), $9.02(\mathrm{~d}, 1 \mathrm{H}$, $J=6.0 \mathrm{~Hz}, \mathrm{CH}$, Heterocycle). ${ }^{13} \mathrm{C}$ NMR $\left(75.5 \mathrm{MHz}, \mathrm{CHCl}_{3}-d_{6}\right): 13.7$ $\left(\mathrm{CH}_{3}\right), 34.1\left(\mathrm{CH}_{3}\right), 104.2(\mathrm{CH}$, Thiazole $), 123.0(\mathrm{CH}, \mathrm{Ar}), 123.6(\mathrm{CH}, \mathrm{Ar})$ 128.0 (CH, Ar), 129.8 (CH, Ar), 130.6 (C-Cl, Ar), 131.0 (C-Cl, Ar), 133.3 (Cq, Ar), 134.1 (CH, Ar), 142.6 (Cq, Heterocycle), $143.4(\mathrm{C}=\mathrm{N}$, Heterocycle), 146.4 (C-N, Heterocycle), $150.6(C=N), 173.8(\mathrm{~N}-\mathrm{C}-\mathrm{S})$. HRMS (ESI): 377.11 [M - H].

\subsubsection{N-[4-(2,4-dichloro-phenyl)-3-methyl-3H-thiazol-2-} ylidene]-N'-(1-pyridin-2-yl-ethylidene)-hydrazine ( $3 k)$

Column chromatography afforded yellowish crystals, yield: $50 \%$ M. p. $\left({ }^{\circ} \mathrm{C}\right): 130-132$. IR $\left(\mathrm{KBr}, \mathrm{cm}^{-1}\right): 1601(\mathrm{C}=\mathrm{N}), 1495(\mathrm{C}=\mathrm{C}) \cdot{ }^{1} \mathrm{H}$ NMR (300 MHz, DMSO-d $\left.d_{6}\right): \delta 2.60\left(\mathrm{~s}, 3 \mathrm{H}, \mathrm{CH}_{3}\right), 3.30\left(\mathrm{~s}, 3 \mathrm{H}, \mathrm{CH}_{3}\right)$, $6.07(\mathrm{~s}, 1 \mathrm{H}, \mathrm{CH}$, Thiazole), $7.30(\mathrm{~m}, 3 \mathrm{H}, \mathrm{CH}, \mathrm{Ar}), 7.54(\mathrm{~d}, 1 \mathrm{H}$, $J=18.0 \mathrm{~Hz}, \mathrm{CH}$, Heterocycle), $7.72(\mathrm{t}, 1 \mathrm{H}, J=17.1$ and $9.0 \mathrm{~Hz}, \mathrm{CH}$ Heterocycle), $8.27(\mathrm{~d}, 1 \mathrm{H}, J=8.4 \mathrm{~Hz}, \mathrm{CH}$, Heterocycle), $8.63(\mathrm{~d}, 1 \mathrm{H}$ $J=7.2 \mathrm{~Hz}, \mathrm{CH}=\mathrm{N}$, Heterocycle). ${ }^{13} \mathrm{C}$ NMR (75.5 MHz, DMSO- $\left.d_{6}\right)$ : $13.2\left(\mathrm{CH}_{3}\right), 32.5\left(\mathrm{CH}_{3}\right), 101.9(\mathrm{CH}$, Thiazole $), 120.8(\mathrm{CH}, \mathrm{Ar}), 122.9$ (CH, Ar), 127.6 (CH, Ar), $128.7(\mathrm{Cq}, \mathrm{Ar}), 129.9(\mathrm{CH}, \mathrm{Ar}), 132.9(\mathrm{CH}, \mathrm{Ar})$, 135.6 (Cq, Ar), 136.2 (CH, Heterocycle), 136.5 (Cq, Ar), 136.6 (Cq, Ar), 148.0 (CH, Heterocycle), 156.3 (Cq, Heterocycle), 156.5 (Cq), 169.9 (Cq). HRMS (ESI): 377.02 [M - H]. 
4.3.12. N-[5-methyl-4-(4-bromo-phenyl)-3-methyl-3H-thiazol-2ylidene]-N'-(1-pyridin-2-yl-ethylidene)-hydrazine (3 l)

Recrystallization from ethanol afforded yellowish crystals, yield: 31\%. M. p. $\left({ }^{\circ} \mathrm{C}\right): 150-152$. IR $\left(\mathrm{KBr}, \mathrm{cm}^{-1}\right): 1555$ and $1527(\mathrm{C}=\mathrm{N})$, $1494(\mathrm{C}=\mathrm{C}) .{ }^{1} \mathrm{H}$ NMR $\left(300 \mathrm{MHz}, \mathrm{DMSO}-d_{6}\right): \delta 3.43\left(\mathrm{~s}, 3 \mathrm{H}, \mathrm{CH}_{3}\right), 3.84$ $\left(\mathrm{s}, 3 \mathrm{H}, \mathrm{CH}_{3}\right), 4.65\left(\mathrm{~s}, 3 \mathrm{H}, \mathrm{CH}_{3}\right), 8.76(\mathrm{t}, 1 \mathrm{H}, J=6.0$ and $12.0 \mathrm{~Hz}, \mathrm{CH}$, Heterocycle), 8.84 (d, $1 \mathrm{H}, J=7.8 \mathrm{~Hz}, \mathrm{CH}, \mathrm{Ar}), 9.20(\mathrm{~m}, 2 \mathrm{H}, \mathrm{CH}$, Heterocycle), 9.40 (d, $2 \mathrm{H}, J=8.1 \mathrm{~Hz}, \mathrm{CH}, \mathrm{Ar}), 9.53(\mathrm{~d}, 1 \mathrm{H}, J=8.1 \mathrm{~Hz}$, $\mathrm{CH}, \mathrm{Ar}), 10.00\left(\mathrm{~d}, 1 \mathrm{H}, J=3.9 \mathrm{~Hz}, \mathrm{CH}=\mathrm{N}\right.$, Heterocycle). ${ }^{13} \mathrm{C} \mathrm{NMR}$ (75.5 MHz, DMSO- $\left.d_{6}\right): 20.2\left(\mathrm{CH}_{3}\right), 33\left(\mathrm{CH}_{3}\right), 43.6\left(\mathrm{CH}_{3}\right), 120.2(\mathrm{Cq}$, Thiazole), 123.6 ( $\mathrm{CH}$, Heterocycle), $129.0(\mathrm{CH}$, Heterocycle), 131.2 (Cq, Ar), 132.4 (2CH, Ar), 132.7 (2CH, Ar), 134.5 (Cq, Ar), $136.6(\mathrm{CH}$, Heterocycle), $149.0(\mathrm{CH}=\mathrm{N}$, Heterocycle), 155.2 (Cq, Heterocycle), 156.6 (Cq), 193.2 (Cq). HRMS (ESI): 401.98 [M - H].

\subsubsection{3. $\mathrm{N}$-[4-(naphthalen-2-yl)-3-methyl-3H-thiazol-2-ylidene]-N'- (1-pyridin-2-yl-ethylidene)-hydrazine $(3 \mathrm{~m})$}

Orange crystals, yield: $53 \%$. M. p. $\left({ }^{\circ} \mathrm{C}\right): 112-125 . \mathrm{IR}\left(\mathrm{KBr}, \mathrm{cm}^{-1}\right)$ : 1585 and $1524(\mathrm{C}=\mathrm{N}), 1417(\mathrm{C}=\mathrm{C}) .{ }^{1} \mathrm{H}$ NMR (400 MHz, DMSO- $\left.d_{6}\right)$ : $\delta 2.46\left(\mathrm{~s}, 3 \mathrm{H}, \mathrm{CH}_{3}\right), 3.29\left(\mathrm{~s}, 3 \mathrm{H}, \mathrm{CH}_{3}-\mathrm{N}\right), 6.80(\mathrm{~s}, 1 \mathrm{H}, \mathrm{CH}$ of Thiazole), $7.62(\mathrm{~m}, 2 \mathrm{H}, \mathrm{CH}, \mathrm{Ar}), 7.78(\mathrm{t}, 1 \mathrm{H}, \mathrm{CH}, \mathrm{Ar}), 8.02(\mathrm{~m}, 4 \mathrm{H}, \mathrm{CH}, \mathrm{Ar}), 8.13$ (d, $1 \mathrm{H}, \mathrm{CH}$, Heterocycle), $8.30(\mathrm{t}, 1 \mathrm{H}, \mathrm{CH}$, Heterocycle), $8.38(\mathrm{t}, 1 \mathrm{H}, \mathrm{CH}$, Heterocycle), $8.71\left(\mathrm{~d}, 1 \mathrm{H}, \mathrm{CH}\right.$, Heterocycle). ${ }^{13} \mathrm{C}$ NMR and DEPT $\left(100 \mathrm{MHz}, \mathrm{DMSO}-d_{6}\right): 13.0\left(\mathrm{CH}_{3}\right), 33.6\left(\mathrm{~N}-\mathrm{CH}_{3}\right), 100.7(\mathrm{CH}$, Thiazole), 119.7 (2CH, Ar); 123.1 (2CH, Ar), 125.9 (C, Ar), 126.7 (CH, Ar), $126.9(\mathrm{CH}, \mathrm{Ar}), 127.6(\mathrm{CH}, \mathrm{Ar}), 128.0(\mathrm{CH}, \mathrm{Ar}), 128.2(\mathrm{C}, \mathrm{Ar}), 132.7(\mathrm{CH}$, Ar), $136.0(C-N, A r), 140.6(C=N$, Heterocycle), $148.5(C-N$, Heterocycle), $155.3(\mathrm{C}=\mathrm{N}), 156.1(\mathrm{~N}-\mathrm{C}-\mathrm{S}, \mathrm{Ar})$.

4.3.14. $N$-(4-phenyl-3-phenyl-3H-thiazol-2-ylidene)- $N$ '-(1-pyridin2-yl-ethylidene)-hydrazine (4a)

Orange crystals, yield: $99 \%$. M. p. $\left({ }^{\circ} \mathrm{C}\right): 232-234$. IR $\left(\mathrm{KBr}, \mathrm{cm}^{-1}\right)$ : $1599(\mathrm{C}=\mathrm{N}) ; 1481(\mathrm{C}=\mathrm{C}) .{ }^{1} \mathrm{H}$ NMR $\left(400 \mathrm{MHz}\right.$, DMSO-d $\left.d_{6}\right): \delta 2.23(\mathrm{~s}$, $\left.3 \mathrm{H}, \mathrm{CH}_{3}\right), 6.90$ (s, $1 \mathrm{H}, \mathrm{CH}$, Thiazole), $7.30(\mathrm{~m}, 10 \mathrm{H}, \mathrm{CH}, \mathrm{Ar}), 7.81(\mathrm{t}, 1 \mathrm{H}$, $J=4.0$ and $12.0 \mathrm{~Hz}, \mathrm{CH}$, Heterocycle), 8.26 (d, $1 \mathrm{H}, J=8.0 \mathrm{~Hz}, \mathrm{CH}$, Heterocycle), $8.39(\mathrm{t}, 1 \mathrm{H}, J=8.0$ and $12.0 \mathrm{~Hz}, \mathrm{CH}$, Heterocycle), 8.73 (d, $1 \mathrm{H}, J=4.0 \mathrm{~Hz}, \mathrm{CH}=\mathrm{N}$, Heterocycle). ${ }^{13} \mathrm{C}$ NMR and DEPT (100 MHz, DMSO- $\left.d_{6}\right)$ : $13.3\left(\mathrm{CH}_{3}\right), 103.4(\mathrm{CH}$, Thiazole $), 123.2(\mathrm{CH}$, $\mathrm{Ar}), 125.1$ (CH, Ar), $128.2(\mathrm{CH}, \mathrm{Ar}), 128.3(\mathrm{CH}, \mathrm{Ar}), 128.38(2 \mathrm{CH}, \mathrm{Ar})$, $128.41(\mathrm{CH}, \mathrm{Ar}), 128.6(\mathrm{CH}, \mathrm{Ar}), 128.8(\mathrm{CH}$, Heterocycle $), 130.2(\mathrm{Cq})$, $137.2(\mathrm{Cq}), 140.1(\mathrm{Cq}), 143.8(\mathrm{CH}=\mathrm{N}$, Heterocycle), 149.5 (Cq, Heterocycle), $150.1(\mathrm{Cq}), 172.5$ (Cq). HRMS (ESI): 371.10 [M+H].

4.3.15. $\mathrm{N}$-(5-methyl-4-phenyl-3-phenyl-3H-thiazol-2-ylidene)-N'(1-pyridin-2-yl-ethylidene)-hydrazine (4b)

Recrystallization from ethanol afforded yellowish crystals, yield: 52\%. M. p. $\left({ }^{\circ} \mathrm{C}\right): 267-269$. IR $\left(\mathrm{KBr}, \mathrm{cm}^{-1}\right): 1523$ and $1494(\mathrm{C}=\mathrm{N})$, $1464(\mathrm{C}=\mathrm{C}) .{ }^{1} \mathrm{H}$ NMR $\left(300 \mathrm{MHz}, \mathrm{DMSO}-d_{6}\right): \delta 2.08\left(\mathrm{~s}, 3 \mathrm{H}, \mathrm{CH}_{3}\right), 2.18$ $\left(\mathrm{s}, 3 \mathrm{H}, \mathrm{CH}_{3}\right), 7.22(\mathrm{~m}, 11 \mathrm{H}, \mathrm{CH}, \mathrm{Ar}), 7.79(\mathrm{t}, 1 \mathrm{H}, J=7.8$ and $17.1 \mathrm{~Hz}, \mathrm{CH}$ Heterocycle), 8.09 (d, $1 \mathrm{H}, J=7.8 \mathrm{~Hz}, \mathrm{CH}$, Heterocycle), 8.54 (d, $1 \mathrm{H}$, $J=4.8 \mathrm{~Hz}, \mathrm{CH}=\mathrm{N}$, Heterocycle). ${ }^{13} \mathrm{C}$ NMR and DEPT $(75 \mathrm{MHz}$, DMSO-d $\left.d_{6}\right): 13.1\left(\mathrm{CH}_{3}\right), 13.7\left(\mathrm{CH}_{3}\right), 111.9$ (Cq, Thiazole), $120.3(\mathrm{CH}$, Ar), 123.9 ( $\mathrm{CH}, \mathrm{Ar}), 127.9$ ( $\mathrm{CH}, \mathrm{Ar}), 128.7$ (2CH, Ar), 128.79 (2CH, Ar), 128.94 (2CH, Ar), 128.99 (2CH, Ar), 130.2 ( $\mathrm{CH}$, Heterocycle), 130.5 (Cq, Ar), 135.0 (CH, Heterocycle), 136.6 (Cq, Ar), 138.4 (Cq, Ar), 149.1 (CH, Heterocycle), 156.3 (Cq, Heterocycle), 156.6 (Cq), 169.0 (Cq Ar). HRMS (ESI): 384.14 [M - H].

4.3.16. $N$-\{[4-(1,1'-biphenyl)-4-yl]-3-phenyl-3H-thiazol-2-ylidene $\}$ $N^{\prime}$-(1-pyridin-2-yl-ethylidene)-hydrazine (4c)

Orange crystals, yield: $100 \%$ M. p. $\left({ }^{\circ} \mathrm{C}\right): 202-204 . \mathrm{IR}\left(\mathrm{KBr}, \mathrm{cm}^{-1}\right)$ : $1616(\mathrm{C}=\mathrm{N}), 1438$ and $1478(\mathrm{C}=\mathrm{C}) .{ }^{1} \mathrm{H}$ NMR $\left(400 \mathrm{MHz}, \mathrm{DMSO}-d_{6}\right)$ : $\delta 2.24\left(\mathrm{~s}, 3 \mathrm{H}, \mathrm{CH}_{3}\right), 6.98(\mathrm{~s}, 1 \mathrm{H}, \mathrm{CH}$, Thiazole), $7.27(\mathrm{~m}, 8 \mathrm{H}, \mathrm{CH}, \mathrm{Ar})$, 7.39 ( $\mathrm{m}, 8 \mathrm{H}, \mathrm{CH}, \mathrm{Ar}), 7.57$ (d, 2H, CH, Ar), 7.62 (d, 2H, CH, Ar), 7.82 (t, $1 \mathrm{H}, \mathrm{CH}$, Heterocycle), $8.27(\mathrm{~d}, 1 \mathrm{H}, \mathrm{CH}$, Heterocycle), $8.40(\mathrm{t}, 1 \mathrm{H}, \mathrm{CH}$,
Heterocycle), $8.74\left(\mathrm{~d}, 1 \mathrm{H}, \mathrm{CH}=\mathrm{N}\right.$, Heterocycle). ${ }^{13} \mathrm{C}$ NMR and DEPT $\left(100 \mathrm{MHz}, \mathrm{DMSO}-d_{6}\right): 13.3\left(\mathrm{CH}_{3}\right), 103.7(\mathrm{CH}$, Thiazole $) ; 123.2(\mathrm{CH}$, $\mathrm{Ar}) ; 125.1$ (CH, Ar); 126.4 (3CH, Ar); 127.8 (C, Ar); 128.3 (3CH, Ar); 128.4 (2CH, Ar); 128.8 (2CH, Ar); 128.9 (2CH, Heterocycle); 129.3 $(\mathrm{CH}=\mathrm{N}$, Heterocycle); 137.2 (C, Ar); 138.8 (C, Ar); 139.7 (Cq, Heterocycle); $140.0(\mathrm{C}-\mathrm{N}$, Heterocycle); $143.8(\mathrm{Cq}=\mathrm{N}) ; 172(\mathrm{~N}-\mathrm{Cq}-\mathrm{S})$. HRMS (ESI): 447.26 [M - H].

4.3.17. N-[4-(4-methoxy-phenyl)-3-phenyl-3H-thiazol-2-ylidene]$N$ '-(1-pyridin-2-yl-ethylidene)-hydrazine (4d)

Reddish crystals, yield: $60 \%$ M. p. $\left({ }^{\circ} \mathrm{C}\right): 217-219 . \mathrm{IR}\left(\mathrm{KBr}, \mathrm{cm}^{-1}\right)$ : $1601(\mathrm{C}=\mathrm{N}), 1477$ and $1438(\mathrm{C}=\mathrm{C}), 1252(\mathrm{C}-\mathrm{O}-\mathrm{C}) \cdot{ }^{1} \mathrm{H}$ NMR (400 MHz, DMSO- $d_{6}$ ): $\delta 2.22\left(\mathrm{~s}, 3 \mathrm{H}, \mathrm{CH}_{3}\right), 3.70\left(\mathrm{~s}, 3 \mathrm{H}, \mathrm{CH}_{3}-\mathrm{O}\right), 6.80$ (d, 3H, CH, Ar), 7.11 (d, 2H, CH, Ar), 7.35 (m, 5H, CH, Ar), $7.81(\mathrm{t}, 1 \mathrm{H}$, $\mathrm{CH}, \mathrm{Ar}), 8.25(\mathrm{~d}, 1 \mathrm{H}, \mathrm{CH}$, Heterocycle), 8.40 (t, $1 \mathrm{H}, \mathrm{CH}$, Heterocycle), $8.72\left(\mathrm{t}, 1 \mathrm{H}, \mathrm{CH}\right.$, Heterocycle). ${ }^{13} \mathrm{C}$ NMR and DEPT (100 MHz, DMSO$\left.d_{6}\right): 13.3\left(\mathrm{CH}_{3}\right), 55.2\left(\mathrm{CH}_{3}\right), 102.2(\mathrm{CH}, \mathrm{Ar}), 113.7(\mathrm{CH}, \mathrm{Ar}), 122.5(\mathrm{CH}$, $\mathrm{Ar}), 123.2(\mathrm{Cq}, \mathrm{Ar}), 125.1(\mathrm{CH}, \mathrm{Ar}), 126.4(\mathrm{CH}, \mathrm{Ar}), 128.2(\mathrm{CH}, \mathrm{Ar})$, $128.3(\mathrm{CH}, \mathrm{Ar}), 128.5(\mathrm{CH}, \mathrm{Ar}), 128.9(\mathrm{CH}, \mathrm{Ar}), 129.8(\mathrm{CH}$, Heterocycle), 137.25 (Cq, Ar), 140.0 (CH, Heterocycle), 143.7 (CH, Heterocycle), 159.3 (Cq, Ar), $172.6(\mathrm{CH}=\mathrm{N}$, Heterocycle). HRMS (ESI): 401.14 [M - H].

4.3.18. $\mathrm{N}$-[4-(4-fluor-phenyl)-3-phenyl-3H-thiazol-2-ylidene]-N'-

(1-pyridin-2-yl-ethylidene)-hydrazine (4e)

Recrystallization from ethanol afforded yellowish crystals, yield: 31\%. M. p. $\left({ }^{\circ} \mathrm{C}\right): 171-173$. IR $\left(\mathrm{KBr}, \mathrm{cm}^{-1}\right): 1597(\mathrm{C}=\mathrm{N}), 1524$ and 1502 $(\mathrm{C}=\mathrm{C}) .{ }^{1} \mathrm{H}$ NMR $\left(300 \mathrm{MHz}, \mathrm{DMSO}-d_{6}\right): \delta 2.22\left(\mathrm{~s}, 3 \mathrm{H}, \mathrm{CH}_{3}\right), 6.70(\mathrm{~s}$, $1 \mathrm{H}, \mathrm{CH}$, Thiazole), 7.10 (t, 2H, CH, Heterocycle), $7.35(\mathrm{~m}, 7 \mathrm{H}, \mathrm{CH}, \mathrm{Ar})$, 7.83 (td, 1H, CH, Ar), 7.83 (dt, 2H, CH, Heterocycle), 8.10 (d, 1H, CH, Heterocycle), $8.56\left(\mathrm{td}, 2 \mathrm{H}, \mathrm{CH}=\mathrm{N}\right.$, Heterocycle). ${ }^{13} \mathrm{C}$ NMR and DEPT (75 MHz, DMSO- $\left.d_{6}\right): 13.4\left(\mathrm{CH}_{3}\right), 102.2(\mathrm{CH}$, Thiazole), $123.5(\mathrm{CH}, \mathrm{Ar})$, $124.1(\mathrm{CH}, \mathrm{Ar}), 125.5$ (CH, Ar), $126.2(\mathrm{CH}, \mathrm{Ar}), 127.2$ (Cq, Ar), 127.8 (Cq, Ar), $128.1(\mathrm{CH}, \mathrm{Ar}), 128.5(\mathrm{CH}, \mathrm{Ar}), 128.8(\mathrm{CH}, \mathrm{Ar}), 130.5(\mathrm{CH}$, Heterocycle), 130.6 ( $\mathrm{CH}$, Heterocycle), 136.3 ( $\mathrm{CH}$, Heterocycle), 137.4 (Cq), 138.6 (Cq, Ar), 148.5 ( $\mathrm{C}=\mathrm{N}$, Heterocycle), 155.7 (Cq-N, Heterocycle), $156.7(\mathrm{Cq}=\mathrm{N}), 169.8(\mathrm{Cq}, \mathrm{Ar}), 177.3(\mathrm{Cq}-\mathrm{F})$. HRMS (ESI): 389.15 [M - H].

\subsubsection{9. $N$-[4-(4-chloro-phenyl)-3-phenyl-3H-thiazol-2-ylidene]-N'-}

(1-pyridin-2-yl-ethylidene)-hydrazine (4f)

Orange crystals, yield: $99 \%$. M. p. $\left({ }^{\circ} \mathrm{C}\right): 246-248$. IR $\left(\mathrm{KBr}, \mathrm{cm}^{-1}\right)$ : $1616(\mathrm{C}=\mathrm{N}), 1480$ and $1444(\mathrm{C}=\mathrm{C}) .{ }^{1} \mathrm{H}$ NMR $\left(400 \mathrm{MHz}\right.$, DMSO- $\left.d_{6}\right)$ : $\delta 2.23\left(\mathrm{~s}, 3 \mathrm{H}, \mathrm{CH}_{3}\right), 6.95$ (s, 1H, CH, Thiazole), 7.21 (d, 2H, CH, Ar), $7.37(\mathrm{~m}, 7 \mathrm{H}, \mathrm{CH}, \mathrm{Ar}), 7.79(\mathrm{t}, 1 \mathrm{H}, \mathrm{CH}$, Heterocycle), $8.25(\mathrm{~d}, 1 \mathrm{H}, \mathrm{CH}$, Heterocycle), $8.37(\mathrm{t}, 1 \mathrm{H}, \mathrm{CH}$, Heterocycle), $8.73(\mathrm{~d}, 1 \mathrm{H}, \mathrm{CH}$, Heterocycle). ${ }^{13} \mathrm{C}$ NMR and DEPT (100 MHz, DMSO- $\left.d_{6}\right): 13.3\left(\mathrm{CH}_{3}\right)$, 104.1 (CH, Ar), 123.1 (CH, Ar), 125.1 (CH, Ar), 128.3 (CH, Ar), 128.4 (CH, Ar), 128.9 (CH, Ar), 129.1 (Cq, Ar), 130.2 (CH, Heterocycle), 133.4 (Cq, Ar), 137.0 (Cq, Ar), 138.8 (Cq, Heterocycle), 143.4 (CH, Heterocycle), $144.1(\mathrm{CH}=\mathrm{N}$, Heterocycle), $150.3(\mathrm{Cq}), 172.2$ (Cq, Ar). HRMS (ESI): 405.09 [M - H]

\subsubsection{0. $\mathrm{N}$-[4-(4-bromo-phenyl)-3-phenyl-3H-thiazol-2-ylidene]-} $N^{\prime}$-(1-pyridin-2-yl-ethylidene)-hydrazine (4 g)

Orange crystals, yield: $94 \%$ M. p. $\left({ }^{\circ} \mathrm{C}\right): 243-245$. IR $\left(\mathrm{KBr}, \mathrm{cm}^{-1}\right)$ : $1615(\mathrm{C}=\mathrm{N}), 1479$ and $1444(\mathrm{C}=\mathrm{C}) .{ }^{1} \mathrm{H}$ NMR (400 MHz, DMSO- $\left.d_{6}\right)$ : $\delta 2.23\left(\mathrm{~s}, 3 \mathrm{H}, \mathrm{CH}_{3}\right), 6.96(\mathrm{~s}, 1 \mathrm{H}, \mathrm{CH}$, Thiazole), $7.13(\mathrm{~d}, 2 \mathrm{H}, \mathrm{CH}, \mathrm{Ar})$, $7.40(\mathrm{~m}, 7 \mathrm{H}, \mathrm{CH}, \mathrm{Ar}), 7.80(\mathrm{t}, 1 \mathrm{H}, \mathrm{CH}$, Heterocycle), $8.25(\mathrm{~d}, 1 \mathrm{H}, \mathrm{CH}$, Heterocycle), 8.38 (t, 1H, CH, Heterocycle), 8.73 (d, 1H, CH, Heterocycle). ${ }^{13} \mathrm{C}$ NMR and DEPT $\left(100 \mathrm{MHz}\right.$, DMSO- $\left.d_{6}\right): 13.8\left(\mathrm{CH}_{3}\right)$, 104.6 (CH, Thiazole), $122.6(\mathrm{Cq}, \mathrm{Ar}), 123.6(\mathrm{CH}, \mathrm{Ar}), 125.6(\mathrm{CH}, \mathrm{Ar})$, 128.8 (CH, Ar), 128.9 (CH, Ar), 129.4 (CH, Ar), 129.9 (Cq, Ar), 130.9 (CH, Ar), 131.8 (CH, Heterocycle), 137.4 (Cq, Ar), 139.4 (Cq, Heterocycle), $143.9(\mathrm{CH}$, Heterocycle), $144.5(\mathrm{CH}=\mathrm{N}$, Heterocycle), 150.7 
(Cq, Ar), 172.7 (Cq, Ar). HRMS (ESI): 449.04 [M - H].

4.3.21. $N$-[4-(4-nitro-phenyl)-3-phenyl-3H-thiazol-2-ylidene]-N'-

(1-pyridin-2-yl-ethylidene)-hydrazine ( $4 \mathrm{~h}$ )

Recrystallization from ethanol afforded reddish crystals, yield: 68\%. M. p. $\left({ }^{\circ} \mathrm{C}\right): 243-246$. IR $\left(\mathrm{KBr}, \mathrm{cm}^{-1}\right): 1606(\mathrm{C}=\mathrm{N}), 1532$ and $1515(\mathrm{C}=\mathrm{C}), 1341\left(\mathrm{NO}_{2}\right) .{ }^{1} \mathrm{H}$ NMR $\left(300 \mathrm{MHz}, \mathrm{DMSO}-d_{6}\right): \delta 2.23(\mathrm{~s}$, $\left.3 \mathrm{H}, \mathrm{CH}_{3}\right), 7.01(\mathrm{~s}, 1 \mathrm{H}, \mathrm{CH}$, Thiazole), $7.40(\mathrm{~m}, 8 \mathrm{H}, \mathrm{CH}, \mathrm{Ar}), 7.82(\mathrm{t}, 1 \mathrm{H}$, $J=7.0$ and $14.09 \mathrm{~Hz}, \mathrm{CH}$, Heterocycle), 8.09 (d, $3 \mathrm{H}, J=8.4 \mathrm{~Hz}, \mathrm{CH}$, Ar), $8.56(\mathrm{~d}, 1 \mathrm{H}, J=4.5 \mathrm{~Hz}, \mathrm{CH}=\mathrm{N}$, Heterocycle $) .{ }^{13} \mathrm{C}$ NMR and DEPT (75 MHz, DMSO-d $)$ ): $13.5\left(\mathrm{CH}_{3}\right), 106.1(\mathrm{CH}$, Thiazole), $119.9(\mathrm{CH}, \mathrm{Ar})$, 123.5 (CH, Ar), 123.7 ( CH, Ar), 128.1 (2CH, Ar), 128.3 (2CH, Ar), 128.9 ( $\mathrm{CH}$, Heterocycle), 129.1 (2CH, Ar), 136.4 (2CH, Ar), 136.9 (CH, Heterocycle), 137.3 (Cq-N, Ar), $137.7\left(C-\mathrm{NO}_{2}\right), 146.8$ (Cq, Ar), 148.7 (C= $\mathrm{N}$, Heterocycle), $155.6(\mathrm{Cq}-\mathrm{N}$, Heterocycle $), 157.5(\mathrm{Cq}=\mathrm{N}), 169.6(\mathrm{~N}-$ Cq-S). HRMS (ESI): 416.11 [M+H].

4.3.22. N-[4-(3-nitro-phenyl)-3-phenyl-3H-thiazol-2-ylidene]-N'-

(1-pyridin-2-yl-ethylidene)-hydrazine (4i)

Recrystallization from ethanol afforded orange crystals, yield: $100 \%$. M. p. $\left({ }^{\circ} \mathrm{C}\right): 150-152$. IR $\left(\mathrm{KBr}, \mathrm{cm}^{-1}\right): 1601(\mathrm{C}=\mathrm{N}), 1524(\mathrm{C}=\mathrm{C})$, $1347\left(\mathrm{NO}_{2}\right) .{ }^{1} \mathrm{H}$ NMR $\left(400 \mathrm{MHz}\right.$, DMSO-d $\left.{ }_{6}\right): \delta 2.23\left(\mathrm{~s}, 3 \mathrm{H}, \mathrm{CH}_{3}\right), 7.00$ (s, 1H, CH Thiazole), 7.38 (m, 5H, CH, Ar), 7.59 (m, 3H, CH, Ar), 7.86 $(\mathrm{s}, 1 \mathrm{H}, \mathrm{CH}, \mathrm{Ar}), 8.06(\mathrm{~m}, 3 \mathrm{H}, \mathrm{CH}$, Heterocycle), $8.57(\mathrm{~d}, 1 \mathrm{H}, \mathrm{CH}=\mathrm{N}$, Heterocycle). ${ }^{13} \mathrm{C}$ NMR and DEPT (100 MHz, DMSO- $\left.d_{6}\right): 13.5\left(\mathrm{CH}_{3}\right)$, 104.7 (CH, Thiazole), $119.9(\mathrm{CH}, \mathrm{Ar}), 122.8(\mathrm{CH}, \mathrm{Ar}), 123.1(\mathrm{CH}, \mathrm{Ar})$, 123.7 (CH, Ar), 128.1 (CH, Ar), 128.5 ( CH, Ar), 128.9 (CH, Ar), 129.8 (CH, Ar), 132.1 (CH, Ar), 134.4 (Cq, Ar), 136.4 (CH, Heterocycle), 137.2 (CH, Heterocycle), 137.4 (CH, Heterocycle), $147.4(\mathrm{Cq}), 148.6(\mathrm{CH}$, Heterocycle), 155.6 (Cq, Heterocycle), 157.1 (Cq), 169.6 (Cq). HRMS (ESI): $416.04[\mathrm{M}+\mathrm{H}]$.

4.3.23. N-[4-(3,4-dichloro-phenyl)-3-phenyl-3H-thiazol-2ylidene]-N'-(1-pyridin-2-yl-ethylidene)-hydrazine (4j)

Orange crystals, yield: $100 \%$. M. p. $\left({ }^{\circ} \mathrm{C}\right): 227-229$. IR $\left(\mathrm{KBr}, \mathrm{cm}^{-1}\right)$ : 1616 and $1587(\mathrm{C}=\mathrm{N}), 1482$ and $1442(\mathrm{C}=\mathrm{C}) .{ }^{1} \mathrm{H}$ NMR $(400 \mathrm{MHz}$, DMSO- $\left.d_{6}\right): \delta 2.23\left(\mathrm{~s}, 3 \mathrm{H}, \mathrm{CH}_{3}\right), 7.05(\mathrm{~s}, 1 \mathrm{H}, \mathrm{CH}$, Thiazole), $7.12(\mathrm{~d}, 1 \mathrm{H}$, $\mathrm{CH}, \mathrm{Ar}), 7.45$ (m, 7H, CH, Ar), 7.74 (t, 1H, CH, Heterocycle), 8.23 (d, $1 \mathrm{H}, \mathrm{CH}$, Heterocycle), $8.30(\mathrm{t}, 1 \mathrm{H}, \mathrm{CH}$, Heterocycle), $8.70(\mathrm{~d}, 1 \mathrm{H}, \mathrm{CH}$, Heterocycle). ${ }^{13} \mathrm{C}$ NMR and DEPT (100 MHz, DMSO- $\left.d_{6}\right): 13.4\left(\mathrm{CH}_{3}\right)$, $105.1(\mathrm{CH}$, Thiazole), $122.7(\mathrm{CH}, \mathrm{Ar}), 124.9(\mathrm{CH}, \mathrm{Ar}), 128.4(\mathrm{CH}, \mathrm{Ar})$, 129.0 (CH, Ar), 130.3 (CH, Ar), 130.4 (CH, Ar), 130.8 (Cq, Ar), 131.0 (Cq, Ar), 131.3 (Cq, Heterocycle), 136.9 (Cq, Ar), $137.4(\mathrm{Cq}), 142.6(\mathrm{CH}$, Heterocycle), 144.6 (CH, Heterocycle), 150.9 (CH, Heterocycle), 171.7 $(\mathrm{CH}=\mathrm{N}$, Heterocycle). HRMS (ESI): 439.01 [M - H].

4.3.24. $\mathrm{N}$-[4-(2,4-dichloro-phenyl)-3-phenyl-3H-thiazol-2-

ylidene]-N'-(1-pyridin-2-yl-ethylidene)-hydrazine (4k)

Brownish crystals, yield: $30 \%$ M. p. $\left({ }^{\circ} \mathrm{C}\right): 177-179$. IR $(\mathrm{KBr}$, $\left.\mathrm{cm}^{-1}\right): 1604(\mathrm{C}=\mathrm{N}), 1583$ and $1522(\mathrm{C}=\mathrm{C}) .{ }^{1} \mathrm{H}$ NMR $(400 \mathrm{MHz}$, DMSO- $\left.d_{6}\right): \delta 2.21\left(\mathrm{~s}, 3 \mathrm{H}, \mathrm{CH}_{3}\right), 6.72(\mathrm{~s}, 1 \mathrm{H}, \mathrm{CH}$, Thiazole $), 7.31(\mathrm{~m}, 6 \mathrm{H}$, $\mathrm{CH}, \mathrm{Ar}), 7.42(\mathrm{~d}, 1 \mathrm{H}, \mathrm{CH}, \mathrm{Ar}), 7.57(\mathrm{~d}, 2 \mathrm{H}, \mathrm{CH}, \mathrm{Ar}), 7.83(\mathrm{t}, 1 \mathrm{H}, \mathrm{CH}$, Heterocycle), 8.10 (d, 1H, CH, Heterocycle), $8.56(\mathrm{~d}, 1 \mathrm{H}, \mathrm{CH}$, Heterocycle). ${ }^{13} \mathrm{C}$ NMR and DEPT (100 MHz, DMSO- $\left.d_{6}\right): 13.4\left(\mathrm{CH}_{3}\right)$, 104.1 (CH, Thiazole), $119.9(\mathrm{CH}, \mathrm{Ar}), 123.6(\mathrm{CH}, \mathrm{Ar}), 127.3(\mathrm{CH}, \mathrm{Ar})$, 127.9 (CH, Ar), 128.2 (CH, Ar), 128.5 (CH, Ar), 128.9 (CH, Ar), 129.0 (Cq, Ar), 134.1 (CH, Heterocycle), 134.2 (Cq, Ar), 134.9 (Cq, Ar), 135.0 $(\mathrm{Cq}, \mathrm{Ar}), 136.4(\mathrm{Cq}, \mathrm{Ar}), 136.6(\mathrm{CH}$, Heterocycle), $148.6(\mathrm{CH}=\mathrm{N}$, Heterocycle), 155.6 (Cq, Heterocycle), 156.8 (Cq), 169.1 (Cq, Ar). HRMS (ESI): 439.05 [M - H].

4.3.25. N-[5-methyl-4-(4-bromo-phenyl)-3-phenyl-3H-thiazol-2ylidene--N'-(1-pyridin-2-yl-ethylidene)-hydrazine (4l)

Recrystallization from ethanol afforded yellowish crystals, yield: 30\%. M. p. $\left({ }^{\circ} \mathrm{C}\right): 174-176$. IR $\left(\mathrm{KBr}, \mathrm{cm}^{-1}\right): 1599$ and $1525(\mathrm{C}=\mathrm{N})$,
$1464(\mathrm{C}=\mathrm{C}) .{ }^{1} \mathrm{H}$ NMR $\left(300 \mathrm{MHz}\right.$, DMSO- $\left.d_{6}\right): \delta 2.09\left(\mathrm{~s}, 3 \mathrm{H}, \mathrm{CH}_{3}\right), 2.19$ (s, 3H, $\mathrm{CH}_{3}$ ), 7.15 (d, 2H, CH, Ar), 7.30 (m, 6H, CH, Ar), 7.48 (d, 2H, CH, $\mathrm{Ar}), 7.81(\mathrm{t}, 1 \mathrm{H}, \mathrm{CH}$, Heterocycle), $8.09(\mathrm{~d}, 1 \mathrm{H}, \mathrm{CH}$, Heterocycle), 8.55 (d, $1 \mathrm{H}, \mathrm{CH}=\mathrm{N}$, Heterocycle). ${ }^{13} \mathrm{C}$ NMR and DEPT (75 MHz, DMSO$\left.d_{6}\right)$ : $12.5\left(\mathrm{CH}_{3}\right), 13.2\left(\mathrm{CH}_{3}\right), 95.8(\mathrm{CH}$, Thiazole $), 119.8(\mathrm{CH}, \mathrm{Ar}), 121.7$ ( $\mathrm{CH}, \mathrm{Ar}), 123.6(\mathrm{CH}, \mathrm{Ar}), 127.6(\mathrm{CH}, \mathrm{Ar}), 128.4(\mathrm{CH}$, Heterocycle), $128.6(\mathrm{CH}$, Heterocycle), $131.2(\mathrm{CH}$, Heterocycle $), 132.0(\mathrm{CH}=\mathrm{N}$, Heterocycle), 136.1 (Cq), 148.5 (Cq). HRMS (ESI): 463.02 [M - H].

\subsubsection{6. $\mathrm{N}$-[4-(naphthalen-2-yl)-3-phenyl-3H-thiazol-2-ylidene]-}

$N^{\prime}$-(1-pyridin-2-yl-ethylidene)-hydrazine $(4 \mathrm{~m})$

Recrystallization from ethanol afforded orange crystals, yield: 98\%. M. p. $\left({ }^{\circ} \mathrm{C}\right): 166-168$. IR $\left(\mathrm{KBr}, \mathrm{cm}^{-1}\right): 1619(\mathrm{C}=\mathrm{N}), 1484$ and $1442(\mathrm{C}=\mathrm{C}) .{ }^{1} \mathrm{H}$ NMR $\left(300 \mathrm{MHz}, \mathrm{DMSO}-d_{6}\right): \delta 2.23\left(\mathrm{~s}, 3 \mathrm{H}, \mathrm{CH}_{3}\right), 6.80$ (s, $1 \mathrm{H}, \mathrm{CH}$, Thiazole), $7.17(\mathrm{~d}, 1 \mathrm{H}, J=8.1 \mathrm{~Hz}, \mathrm{CH}, \mathrm{Ar}), 7.32(\mathrm{~m}, 5 \mathrm{H}, \mathrm{CH}$, $\mathrm{Ar}), 7.51(\mathrm{~m}, 2 \mathrm{H}, \mathrm{CH}, \mathrm{Ar}), 7.77(\mathrm{~m}, 6 \mathrm{H}, \mathrm{CH}, \mathrm{Ar}), 8.10(\mathrm{~d}, 1 \mathrm{H}, J=8.1 \mathrm{~Hz}$, $\mathrm{CH}$, Heterocycle), $8.55\left(\mathrm{~d}, 1 \mathrm{H}, J=4.2 \mathrm{~Hz}, \mathrm{CH}=\mathrm{N}\right.$, Heterocycle). ${ }^{13} \mathrm{C}$ NMR and DEPT (75 MHz, DMSO- $\left.d_{6}\right): 13.2\left(\mathrm{CH}_{3}\right), 103.0(\mathrm{CH}$, Thiazole), 123.1 ( $\mathrm{CH}, \mathrm{Ar}), 125.1(\mathrm{CH}, \mathrm{Ar}), 125.5(\mathrm{CH}, \mathrm{Ar}), 126.7(\mathrm{CH}, \mathrm{Ar})$, 126.9 (CH, Ar), 127.5 (CH, Ar), $127.6(\mathrm{CH}, \mathrm{Ar}), 127.8(\mathrm{CH}, \mathrm{Ar}), 127.9$ (Cq, Ar), 128 (C, Ar), 128.2 (CH, Ar), 128.4 (CH, Heterocycle), 128.9 (CH, Heterocycle), 132.1 (Cq, Ar), 137.3 (Cq, Ar), 140.0 (Cq, Heterocycle), $143.6(\mathrm{CH}$, Heterocycle $), 143.9(\mathrm{CH}=\mathrm{N}$, Heterocycle), 150 $(\mathrm{Cq}=\mathrm{N}), 172(\mathrm{Cq})$. HRMS (ESI): $421.14[\mathrm{M}-\mathrm{H}]$.

\subsection{Cells}

J774A.1 macrophage cell line was cultured in DMEM medium (Cultilab, São Paulo, Brazil) containing 10\% heat-inactivated fetal bovine serum (FBS) (Cultilab, São Paulo, Brazil), 100U/mL penicillin $\mathrm{G}$, and $2 \mathrm{mMl}$-glutamine in a humidified atmosphere of $5 \% \mathrm{CO}_{2}$ in air at $37{ }^{\circ} \mathrm{C}$. Culture medium was changed 2-3 days and subcultured when cell population density reached to $70-80 \%$ confluence. This cell line was obtained from the cell bank of Rio de Janeiro (BCRJ). T. cruzi Dm28c epimastigotes, cloned derived from Dm28 strain, were maintained at $27^{\circ} \mathrm{C}$ in LIT (Liver Infusion Tryptose) medium supplemented with $10 \%$ FBS, $1 \%$ hemin (Sigma-Aldrich, St. Louis, USA), and $50 \mu \mathrm{g} / \mathrm{mL}$ gentamycin (Novafarma, Anápolis, Brazil). Y strain trypomastigotes were obtained from the supernatant of infected LLC-MK2 cells and were maintained in RPMI-1640 medium (Sigma-Aldrich, St. Louis, USA) supplemented with $10 \%$ FBS, and $50 \mu \mathrm{g} / \mathrm{mL}$ gentamycin at $37{ }^{\circ} \mathrm{C}$ and $5 \% \mathrm{CO}_{2}$.

\subsection{Cytotoxicity in J774A.1 macrophages}

MTT-tetrazolium reduction assay was used to evaluate effects of compounds against J774A.1 cells. Briefly, $1 \times 10^{5}$ cells/well were added in 96 -well plates and incubated for $24 \mathrm{~h}\left(37^{\circ} \mathrm{C}\right.$ and $5 \% \mathrm{CO}_{2}$ ). Compounds were then added in different concentrations $(1-100 \mu \mathrm{g} / \mathrm{mL})$ and incubated for $72 \mathrm{~h}$. MTT (3-(4,5Dimethylthiazol-2-yl)-2,5-diphenyltetrazoliumbromide, $5 \mathrm{mg} / \mathrm{mL}$ in PBS) was added to each well and incubated again for $2 \mathrm{~h}$. Culture medium and MTT not reduced was removed and $100 \mu \mathrm{L}$ of DMSO were added. The amount of formazan was determined by measuring the absorbance at $570 \mathrm{~nm}$. Concentration leading to $50 \%$ inhibition of viability $\left(\mathrm{CC}_{50}\right)$ was calculated by regression analysis with GraphPad Prism Software.

\subsection{Anti-T. cruzi activity (epimastigotes)}

Epimastigotes were distributed into a 96 well plate to a final density of $10^{6}$ cells per well. Each compound was dissolved in the respective wells, in triplicate. Benznidazole was used as positive control in this assay. Plate was then cultivated for 4 days at $27^{\circ} \mathrm{C}$. After this time, aliquots from each well were collected, and the 
number of parasites was calculated in a Neubauer chamber. Epimastigotes not treated with compounds (negative control) were assumed as $100 \%$ the number of parasites. Dose-response curves were determined, and the IC50 values were calculated using at least five concentrations and a nonlinear regression (Prism, version 5.0).

\subsection{Anti- T. cruzi activity (trypomastigotes)}

Trypomastigotes were collected from LLC-MK2 cells supernatants and distributed in a 96 well plate to a final density of $4 \times 10^{5}$ cells per well. Each compound was added to the wells, in triplicate. Benznidazole was used as positive controls in this assay. Plate was then cultivated for $24 \mathrm{~h}$ at $37 \mathrm{C}$ and $5 \% \mathrm{CO}_{2}$. After this time, aliquots from each well were collected, and the number of viable parasites (i.e., with apparent motility) was counted in a Neubauer chamber. Wells that did not receive compound were assumed as $100 \%$ of viable parasites. Dose-response curves were determined, and the IC50 values were calculated by nonlinear regression (Prism, version 5.0) using at least seven concentrations.

\subsection{Assay against cruzain}

Cruzain activity was measured by monitoring the cleavage of the fluorescent substrate Z-Phe-Arg-aminomethylcoumarin (Z-FRAMC). The release of fluorescent 4-amino-7-methylcoumarin was measured at $340 \mathrm{~nm} / 440 \mathrm{~nm}$ wavelengths for excitation/emission, on a Synergy 2 (Biotek) fluorometer of the Centre for Flow Cytometry of the Department of Biochemistry and Immunology at UFMG. All assays were performed in 96-well plate format, in a final volume of $200 \mu \mathrm{L}$ of $0.1 \mathrm{M}$ sodium acetate buffer, $\mathrm{pH} 5.5$, in the presence of $0.1 \mathrm{mM}$ betamercaptoethanol, $0.01 \%$ Triton X-100, $0.5 \mathrm{nM}$ cruzain and $2.5 \mu \mathrm{M}$ of substrate [36]. The assay was performed after a 10-min pre-incubation of the compounds with the enzyme. Initial screening was performed with $50 \mu \mathrm{M}$ of inhibitors, except for $\mathbf{5 j}, \mathbf{6 g}$ and $\mathbf{6 c}$ were assayed with $25 \mu \mathrm{M}$. For each assay, two independent experiments were performed, each in triplicates and monitored for $5 \mathrm{~min}$. Enzymatic activities were calculated by comparison to initial rates of reaction of a DMSO control.

\subsection{Flow cytometry analysis}

Trypomastigotes $\left(4 \times 10^{5}\right.$ cells $\left./ \mathrm{mL}\right)$ were resuspended in RPMI1640 medium and treated with compounds $\mathbf{3 b}, \mathbf{5 g}, \mathbf{6 d}$ and $\mathbf{6 k}(1$ and $2 \mathrm{xIC}_{50}$ ) for $24 \mathrm{~h}$ at $37{ }^{\circ} \mathrm{C}$ with $5 \% \mathrm{CO}_{2}$. Parasites were labeled with propidium iodide (PI) and annexin $\mathrm{V}$ using the annexin $\mathrm{V}$-FITC apoptosis detection kit (Ebioscience, San Diego, USA) according to the manufacturer instructions. Experiment was performed using a BD FACSCalibur flow cytometer (San Jose, USA) by acquiring 20,000 events of the parasite region. Data were analyzed using FlowJo (Tree Star Inc ${ }^{\odot}$, Ashland, USA) and expressed as the percentage of cells in each population phenotype (unstained, stained only with PI, stained only with AV or stained with both markers) compared to the total number of cells analyzed. Two independent experiments, in duplicate, were performed.

\section{Acknowledgments}

This work was funded by Conselho Nacional de Desenvolvimento Científico e Tecnológico, Fundação de Amparo á Ciência e Tecnologia de Pernambuco (FACEPE). Ana Cristina Lima Leite is receiving a CNPq senior fellowship. Authors are thankful to the Departamento de Química Fundamental (DQF-UFPE) for recording the $1 \mathrm{H}$ NMR, 13C NMR, and IR spectra of compounds. We are also thankful to Centro de Tecnologias Estratégicas do Nordeste (CETENE) for recording the MS spectra of compounds. All authors declare no competing financial interest.

\section{Appendix A. Supplementary data}

Supplementary data related to this article can be found at http:// dx.doi.org/10.1016/j.ejmech.2017.02.026.

\section{References}

[1] D.L. Longo, C. Bern, Chagas' disease, N. Engl. J. Med. 373 (2015) 456-466, http://dx.doi.org/10.1056/NEJMra1410150.

[2] WHO, World Health Organization Technical report series, Research priorities for chagas disease, human African trypanosomiasis and leishmaniasis, v-xii, 2012, pp. 1-100, 9789241209755.

[3] P.M.M. Guedes, G.K. Silva, F.R.S. Gutierrez, J.S. Silva, Current status of Chagas disease chemotherapy, Expert Rev. Anti-Infective Ther. 9 (2011) 609-620, http://dx.doi.org/10.1586/eri.11.31.

[4] E.A. Fabiana, S. Machado, A. Linda, Jelicks Louis, V. Kirchhoff, Jamshid Shirani, Fnu Nagajyothi, Shankar Mukherjee, Chagas Heart disease: report on recent developments, Cardiol. Rev. 20 (2013) 53-65, http://dx.doi.org/10.1097/ CRD.0b013e31823efde2.Chagas.

[5] L.A.A. Avelar, C.D. Camilo, S. de Albuquerque, W.B. Fernandes, C. Gonçalez, P.W. Kenny, A. Leitão, J.H. McKerrow, C.A. Montanari, E.V.M. Orozco, J.F.R. Ribeiro, J.R. Rocha, F. Rosini, M.E. Saidel, Molecular design, synthesis and trypanocidal activity of dipeptidyl nitriles as cruzain inhibitors, PLOS Neglected Trop. Dis. 9 (2015) e0003916, http://dx.doi.org/10.1371/ journal.pntd.0003916.

[6] W. Devine, J.L. Woodring, U. Swaminathan, E. Amata, G. Patel, J. Erath, N.E. Roncal, P.J. Lee, S.E. Leed, A. Rodriguez, K. Mensa-Wilmot, R.J. Sciotti, M.P. Pollastri, Protozoan parasite growth inhibitors discovered by crossscreening yield potent scaffolds for lead discovery, J. Med. Chem. 58 (2015) 5522-5537, http://dx.doi.org/10.1021/acs.jmedchem.5b00515.

[7] D.R. Magalhaes Moreira, A.D.T. De Oliveira, P.A. Teixeira De Moraes Gomes, C.A. De Simone, F.S. Villela, R.S. Ferreira, A.C. Da Silva, T.A.R. Dos Santos, M.C.A. Brelaz De Castro, V.R.A. Pereira, A.C.L. Leite, Conformational restriction of aryl thiosemicarbazones produces potent and selective anti-Trypanosoma cruzi compounds which induce apoptotic parasite death, Eur. J. Med. Chem. 75 (2014) 467-478, http://dx.doi.org/10.1016/j.ejmech.2014.02.001.

[8] A.M. Tomas, M.A. Miles, J.M. Kelly, Overexpression of cruzipain, the major cysteine proteinase of Trypanosoma cruzi, is associated with enhanced metacyclogenesis, Eur. J. Biochem./FEBS 244 (1997) 596-603.

[9] P.S. Doyle, Y.M. Zhou, I. Hsieh, D.C. Greenbaum, J.H. McKerrow, J.C. Engel, The Trypanosoma cruzi protease cruzain mediates immune evasion, PLoS Pathog. 7 (2011) e1002139, http://dx.doi.org/10.1371/journal.ppat.1002139.

[10] J.W.P. Espíndola, M.V. de O. Cardoso, G.B. de O. Filho, D.A. Oliveira e Silva, D.R.M. Moreira, T.M. Bastos, C.A. de Simone, M.B.P. Soares, F.S. Villela, R.S. Ferreira, M.C.A.B. de Castro, V.R.A. Pereira, S.M.F. Murta, P.A. Sales Junior, A.J. Romanha, A.C.L. Leite, Synthesis and structure-activity relationship study of a new series of antiparasitic aryloxyl thiosemicarbazones inhibiting Trypanosoma cruzi cruzain, Eur. J. Med. Chem. 101 (2015) 818-835, http:// dx.doi.org/10.1016/j.ejmech.2015.06.048.

[11] R.S. Ferreira, M.A. Dessoy, I. Pauli, M.L. Souza, R. Krogh, A.I.L. Sales, G. Oliva, L.C. Dias, A.D. Andricopulo, Synthesis, biological evaluation, and structure-activity relationships of potent noncovalent and nonpeptidic cruzain inhibitors as anti- Trypanosoma cruzi agents, J. Med. Chem. 57 (2014) 2380-2392, http://dx.doi.org/10.1021/jm401709b.

[12] P.M. Goud, A. Sheri, P.V. Desai, E.B. Watkins, B. Tekwani, Y. Sabnis, J. Gut, P.J. Rosenthal, M.A. Avery, Design, synthesis and evaluation of trisubstituted thiazoles targeting Plasmodium falciparum cysteine proteases, Med. Chem. Res. 14 (2005) 74-105, http://dx.doi.org/10.1007/s00044-005-0126-y.

[13] S.A. Carvalho, L.O. Feitosa, M. Soares, T.E.M.M. Costa, M.G. Henriques, K. Salomão, S.L. de Castro, M. Kaiser, R. Brun, J.L. Wardell, S.M.S.V. Wardell, G.H.G. Trossini, A.D. Andricopulo, E.F. da Silva, C.A.M. Fraga, Design and synthesis of new (E)-cinnamic N-acylhydrazones as potent antitrypanosomal agents, Eur. J. Med. Chem. 54 (2012) 512-521, http://dx.doi.org/10.1016/ j.ejmech.2012.05.041.

[14] N.C. Fonseca, L.F. da Cruz, F. da Silva Villela, G.A. do Nascimento Pereira, J.L. de Siqueira-Neto, D. Kellar, B.M. Suzuki, D. Ray, T.B. de Souza, R.J. Alves, P.A.S. Júnior, A.J. Romanha, S.M.F. Murta, J.H. McKerrow, C.R. affrey, R.B. de Oliveira, R.S. Ferreira, Synthesis of a sugar-based thiosemicarbazone series and structure-activity relationship versus the parasite cysteine proteases rhodesain, cruzain, and schistosoma mansoni cathepsin B1, Antimicrob. Agents Chemother. 59 (2015) 2666-2677, http://dx.doi.org/10.1128/ AAC.04601-14.

[15] D.R.M. Moreira, S.P.M. Costa, M.Z. Hernandes, M.M. Rabello, G.B. de Oliveira Filho, C.M.L. de Melo, L.F. da Rocha, C.A. de Simone, R.S. Ferreira, J.R.B. Fradico, C.S. Meira, E.T. Guimarães, R.M. Srivastava, V.R.A. Pereira, M.B.P. Soares, A.C.L. Leite, Structural investigation of anti- Trypanosoma cruzi 2Iminothiazolidin-4-ones allows the identification of agents with efficacy in infected mice, J. Med. Chem. 55 (2012) 10918-10936, http://dx.doi.org/ 10.1021/jm301518v.

[16] G. Álvarez, J. Martínez, J. Varela, E. Birriel, E. Cruces, M. Gabay, S.M. Leal, 
P. Escobar, B. Aguirre-López, N. Cabrera, M. Tuena de Gómez-Puyou, A. Gómez Puyou, R. Pérez-Montfort, G. Yaluff, S. Torres, E. Serna, N. Vera de Bilbao, M. González, H. Cerecetto, Development of bis-thiazoles as inhibitors of triosephosphate isomerase from Trypanosoma cruzi. Identification of new nonmutagenic agents that are active in vivo, Eur. J. Med. Chem. 100 (2015) 246-256, http://dx.doi.org/10.1016/j.ejmech.2015.06.018.

[17] G.B. de Oliveira Filho, M.V. de Oliveira Cardoso, J.W.P. Espíndola, L.F.G.R. Ferreira, C.A. de Simone, R.S. Ferreira, P.L. Coelho, C.S. Meira, D.R. Magalhaes Moreira, M.B.P. Soares, A.C. Lima Leite, Structural design, synthesis and pharmacological evaluation of 4-thiazolidinones against Trypanosoma cruzi, Bioorg. Med. Chem. 23 (2015) 7478-7486, http://dx.doi.org/ 10.1016/j.bmc.2015.10.048.

[18] L.R.S. Dias, M.B. Santos, S. de Albuquerque, H.C. Castro, A.M.T. de Souza, A.C.C. Freitas, M.A.V. DiVaio, L.M. Cabral, C.R. Rodrigues, Synthesis, in vitro evaluation, and SAR studies of a potential antichagasic 1H-pyrazolo[3,4-b] pyridine series, Bioorg. Med. Chem. 15 (2007) 211-219, http://dx.doi.org/ 10.1016/j.bmc.2006.09.067.

[19] J.A. Lessa, D.C. Reis, I.C. Mendes, N.L. Speziali, L.F. Rocha, V.R.A. Pereira, C.M.L. Melo, H. Beraldo, Antimony(III) complexes with pyridine-derived thiosemicarbazones: structural studies and investigation on the antitrypanosomal activity, Polyhedron 30 (2011) 372-380, http://dx.doi.org/ 10.1016/j.poly.2010.11.004.

[20] M.V.D.O Cardoso, L.R.P. De Siqueira, E.B. Da Silva, L.B. Costa, M.Z. Hernandes, M.M. Rabello, R.S. Ferreira, L.F. da Cruz, D.R.M. Moreira, V.R.A. Pereira, M.C.A.B. de Castro, P.V. Bernhardt, A.C.L. Leite, 2-Pyridyl thiazoles as novel anti- Trypanosoma cruzi agents: structural design, synthesis and pharmacological evaluation, Eur. J. Med. Chem. 86 (2014) 48-59, http://dx.doi.org/ 10.1016/j.ejmech.2014.08.012.

[21] A.C.L. Leite, R.S. de Lima, D.R. de M. Moreira, M.V. de O. Cardoso, A.C. Gouveia de Brito, L.M. Farias dos Santos, M.Z. Hernandes, A.C. Kiperstok, R.S. de Lima, M.B.P. Soares, Synthesis, docking, and in vitro activity of thiosemicarbazones, aminoacyl-thiosemicarbazides and acyl-thiazolidones against Trypanosoma cruzi, Bioorg. Med. Chem. 14 (2006) 3749-3757, http://dx.doi.org/10.1016/ j.bmc.2006.01.034.

[22] M.Z. Hernandes, M.M. Rabello, A.C.L. Leite, M.V.O. Cardoso, D.R.M. Moreira, D.J. Brondani, C.A. Simone, L.C. Reis, M.A. Souza, V.R.A. Pereira, Studies toward the structural optimization of novel thiazolylhydrazone-based potent antitrypanosomal agents, Bioorg. Med. Chem. 18 (2010) 7826-7835, http:// dx.doi.org/10.1016/j.bmc.2010.09.056.

[23] P.A.T. de Moraes Gomes, A.R. Oliveira, M.V. de Oliveira Cardoso, E. de Farias Santiago, M. de Oliveira Barbosa, L.R.P. de Siqueira, D.R.M. Moreira, T.M. Bastos, F.A. Brayner, M.B.P. Soares, A.P. de Oliveira Mendes, M.C.A.B. de Castro, V.R. Alves Pereira, A.C.L. Leite, Phthalimido-thiazoles as building blocks and their effects on the growth and morphology of Trypanosoma cruzi, Eur. J. Med. Chem. 111 (2016) 46-57, http://dx.doi.org/10.1016/ j.ejmech.2016.01.010.

[24] P.A.T. de Moraes Gomes, M. de Oliveira Barbosa, E. Farias Santiago, M.V. de Oliveira Cardoso, N.T. Capistrano Costa, M.Z. Hernandes, D.R.M. Moreira, A.C. da Silva, T.A.R. dos Santos, V.R.A. Pereira, G.A. do Nascimento Pereira, R.S. Ferreira, A.C.L. Leite, New 1,3-thiazole derivatives and their biological and ultrastructural effects on Trypanosoma cruzi, Eur. J.Med. Chem. (2016), http:// dx.doi.org/10.1016/j.ejmech.2016.05.050.

[25] A.J. Romanha, S.L. De Castro, M.D.N.C. Soeiro, J. Lannes-Vieira, I. Ribeiro, A. Talvani, B. Bourdin, B. Blum, B. Olivieri, C. Zani, C. Spadafora, E. Chiari, E. Chatelain, G. Chaves, J.E. Calzada, J.M. Bustamante, L.H. Freitas-Junior,
L.I. Romero, M.T. Bahia, M. Lotrowska, M. Soares, S.G. Andrade, T. Armstrong, W. Degrave, Z.D.A. Andrade, In vitro and in vivo experimental models for drug screening and development for Chagas disease, Memórias Do Inst. Oswaldo Cruz 105 (2010) 233-238, http://dx.doi.org/10.1590/S007402762010000200022 .

[26] M.Z. Hernandes, S.M.T. Cavalcanti, D.R.M. Moreira, W.F. de Azevedo Junior, A.C.L. Leite, Halogen atoms in the modern medicinal chemistry: hints for the drug design, Curr. Drug Targets 11 (2010) 303-314, http://dx.doi.org/ $10.2174 / 138945010790711996$.

[27] J.D. Maya, S. Bollo, L.J. Nuñez-Vergara, J.A. Squella, Y. Repetto, A. Morello, J. Périé, G. Chauvière, Trypanosoma cruzi: effect and mode of action of nitroimidazole and nitrofuran derivatives, Biochem. Pharmacol. 65 (2003) 999-1006, http://dx.doi.org/10.1016/S0006-2952(02)01663-5.

[28] T.M. Bastos, M.I.F. Barbosa, M.M. Da Silva, W.C. Da Jos??, C.S. Meira E.T. Guimaraes, J. Ellena, D.R.M. Moreira, A.A. Batista, M.B.P. Soares, Nitro/ Nitrosyl- Ruthenium complexes are potent and selective anti-Trypanosoma cruzi agents causing autophagy and Necrotic parasite death, Antimicrob. Agents Chemother. 58 (2014) 6044-6055, http://dx.doi.org/10.1128/ AAC.02765-14.

[29] L.B. Costa, M.V. de O. Cardoso, G.B. de Oliveira Filho, P.A.T. de Moraes Gomes, J.W.P. Espíndola, T.G. de Jesus Silva, P.H.M. Torres, F.P. Silva, J. Martin, R.C.B.Q. de Figueiredo, A.C.L. Leite, Compound profiling and 3D-QSAR studies of hydrazone derivatives with activity against intracellular Trypanosoma cruzi, Bioorg. Med. Chem. 24 (2016) 1608-1618, http://dx.doi.org/10.1016/ j.bmc.2016.02.027.

[30] M.E. Caputto, A. Ciccarelli, F. Frank, A.G. Moglioni, G.Y. Moltrasio, D. Vega E. Lombardo, L.M. Finkielsztein, Synthesis and biological evaluation of some novel 1-indanone thiazolylhydrazone derivatives as anti-Trypanosoma cruz agents, Eur. J. Med. Chem. 55 (2012) 155-163, http://dx.doi.org/10.1016/ j.ejmech.2012.07.013.

[31] A.L. Matsuo, L.S. Silva, A.C. Torrecilhas, B.S. Pascoalino, T.C. Ramos, E.G. Rodrigues, S. Schenkman, A.C.F. Caires, L.R. Travassos, In vitro and in vivo trypanocidal effects of the cyclopalladated compound 7a, a drug candidate for treatment of Chagas' disease, Antimicrob. Agents Chemother. 54 (2010) 3318-3325, http://dx.doi.org/10.1128/AAC.00323-10.

[32] C. a Lipinski, F. Lombardo, B.W. Dominy, P.J. Feeney, Experimental and computational approaches to estimate solubility and permeability in drug discovery and developmental settings, Adv. Drug Deliv. Rev. 23 (1997) 3-25, http://dx.doi.org/10.1016/S0169-409X(96)00423-1.

[33] N.A. Meanwell, Improving drug candidates by design: a focus on physicochemical properties as a means of improving compound disposition and safety, 2011, pp. 1420-1456.

[34] M. Cardosoa, M. Hernandes, D. Moreira, F. Pontes, C. Simone, A. Leite, Structural insights into bioactive Thiazolidin-4-one: experimental and theoretica data, Lett. Org. Chem. 12 (2015) 262e270. http://dx.doi.org/10.2174/ 1570178612666150203005612.

[35] M.V.D.O. Cardoso, D.R.M. Moreira, G.B.O. Filho, S.M.T. Cavalcanti, L.C.D. Coelho, J.W.P. Espíndola, et al., Design, synthesis and structureeactivity relationship of phthalimides endowed with dual antiproliferative and immunomodulatory activities, Eur. J. Med. Chem. 96 (2015) 491e503. http://dx.doi.org/10.1016/j. ejmech.2015.04.041.

[36] R.S. Ferreira, C. Bryant, K.K.H. Ang, J.H. McKerrow, B.K. Shoichet, A.R. Renslo, Divergent modes of enzyme inhibition in a homologous structure-activity series, J. Med. Chem. 52 (2009) 5005e5008, http://dx.doi.org/10.1021/ jm9009229. 